\title{
Design and testing of a horizontal rock bed for high temperature thermal energy storage
}

Soprani, Stefano; Marongiu, Fabrizio; Christensen, Ludvig ; Alm, Ole; Petersen, Kenni Dinesen; Ulrich, Thomas; Engelbrecht, Kurt

Published in:

Applied Energy

Link to article, DOI:

10.1016/j.apenergy.2019.113345

Publication date:

2019

Document Version

Peer reviewed version

Link back to DTU Orbit

Citation (APA):

Soprani, S., Marongiu, F., Christensen, L., Alm, O., Petersen, K. D., Ulrich, T., \& Engelbrecht, K. (2019). Design and testing of a horizontal rock bed for high temperature thermal energy storage. Applied Energy, 251, [113345]. https://doi.org/10.1016/j.apenergy.2019.113345

\section{General rights}

Copyright and moral rights for the publications made accessible in the public portal are retained by the authors and/or other copyright owners and it is a condition of accessing publications that users recognise and abide by the legal requirements associated with these rights.

- Users may download and print one copy of any publication from the public portal for the purpose of private study or research.

- You may not further distribute the material or use it for any profit-making activity or commercial gain

- You may freely distribute the URL identifying the publication in the public portal 


\title{
Design and Testing of a Horizontal Rock Bed for High Temperature Thermal Energy Storage
}

Stefano Soprani ${ }^{\mathrm{a}}$, Fabrizio Marongiu ${ }^{\mathrm{a}, \mathrm{b}}$, Ludvig Christensen ${ }^{\mathrm{c}}$, Ole $\mathrm{Alm}^{\mathrm{c}}$, Kenni Dinesen Petersen ${ }^{\mathrm{d}}$, Thomas Ulrich $^{\mathrm{d}}$, Kurt Engelbrecht ${ }^{\mathrm{a}^{*}}$

${ }^{a}$ Department of Energy Conversion and Storage, Technical University of Denmark, Frederiksborgvej 399, 4000 Roskilde, Denmark.

${ }^{\text {b }}$ Polytechnic University of Milano, Piazza Leonardo da Vinci, 32, 20133 Milano, Italy.

${ }^{c}$ SEAS-NVE, www.seas-nve.dk, Hovedgaden 36, DK-4520 Svinninge, Denmark.

${ }^{\mathrm{d}}$ Department for Geoscience, Aarhus University, Høegh Guldbergs Gade 2, 8000 Aarhus, Denmark.

\begin{abstract}
Integration of energy storage infrastructures into electrical grids represents a crucial milestone in the transition towards energy systems with high penetration of renewables. However, the high cost of the currently available technologies is a significant barrier for their implementation on the industrial scale. High temperature thermal energy storage systems, in combination with bottom steam cycles, are being investigated as potential cost-effective alternatives to traditional large-scale energy storage technologies. In this study, the performance of a rock bed high temperature energy storage unit is experimentally investigated. The rock bed has a storage capacity of $450 \mathrm{kWh}_{\mathrm{th}}$, was built to store heat at $600{ }^{\circ} \mathrm{C}$ and is characterized in terms of thermal efficiencies. Charge and discharge cycles were performed for different operating conditions and the temperature distribution across the bed was analyzed. A particular focus was set on the study of the impact of buoyancy forces on the temperature gradient inside the bed and on the storage unit efficiency. Different charging powers, flow concepts and rock bed configurations were discussed to optimize storage operations and led to an improvement in efficiency of the charging phase of $17 \%$. A thermal round trip efficiency of around $68 \%$ was estimated for the best configurations and different improvement approaches were discussed for future research.
\end{abstract}

\section{Introduction}

Renewable energy sources (RES) such as wind and solar power are intermittent and unpredictable. At the same time, there is a strong time-dependence on electricity demands in the electricity grid that does not necessarily correspond to RES power production. As the fraction of electricity production from renewable sources continues to grow, the need for energy storage to shift RES power production curves to match demand as part of the electricity grid becomes increasingly important [1]. In this way, energy storage is an enabling technology for RES [2]. A grid with a high mix of RES but little or no energy storage capacity will face challenges from both the grid and market sides [3], [4]. For example Denmark currently has more than $20 \%$ of its electricity provided by renewables, mostly wind, and during certain periods wind power can more than meet the entire electricity demand. This causes large fluctuations in electricity prices and makes Denmark an attractive market for electricity storage [5]. 
Energy storage is a promising solution to the issues mentioned above. It can be utilized (i) for regulation and grid balancing, e.g. stabilizing the power output of RES plants, covering the imbalance between demand and production, (ii) to give a capacity reserve, e.g. ensuring energy availability in periods of peak demand or in case of failures in the grid, and (iii) to give stability to spot market prices in large scale applications, e.g. storing relatively inexpensive base-load electricity during off-peak weekly or seasonal periods, and selling it back during peak periods [6]. Along with this, however, the main issue of a great number of the current technologies is the excessive capital cost, which can prevent them from being successful in a market with no incentive schemes [7].

As presented in [8] many energy storage technologies have been studied: solid state batteries [9], flow batteries [10], flywheels [11], compressed air energy storage (CAES) [12], thermal energy storage (TES) [13], pumped hydro [14], electrolysis [15] and others. Recent thermal energy storage solutions include a "Brayton Battery" [16] which is based on a turbine operating between a heated thermal reservoir and a cooled thermal reservoir. A model of a similar concept with a high temperature, high pressure reservoir coupled to a low pressure low temperature reservoir via a turbo pump and turbo expander electricity generator was describe by [17]. Three different types of thermal energy storage are generally studied [18]: thermo-chemical (e.g. ammonia dissociation) [19], latent heat (e.g. ice, salt hydrates, paraffins) [20], or sensible heat (e.g. water, sand, concrete, rocks) [21]. Rock beds can also be implemented in direct-contact adiabatic CAES applications [22]. TES technologies can be implemented in power-to-power applications where electricity is converted at high temperature, around $600^{\circ} \mathrm{C}$ or higher, during low electricity price periods and then is re-converted into electricity via a bottom steam cycle when electricity during high electricity price periods. A high temperature sensible heat storage system is a promising energy storage technology in terms of cost, scale and the possibility to work over a wide temperature range. The heat stored can be used both for electricity production from an external power cycle, directly for district heating or for industrial applications.

\subsection{High temperature thermal energy storage in rock beds}

High temperature thermal energy storage (HTTES) rock-bed units convert low cost electricity to high temperature heat, either using electrical heaters or a heat pump. Air is used as the heat transfer fluid to transfer heat to the rock bed, as well as to recover heat and produce steam in a heat recovery steam generator (HRSG), which interfaces with a bottom steam cycle. Concentrated solar power (CSP) plants can use HTTES rock beds in order to decouple the solar field availability from the power production [23]. The main advantages associated with HTTES are: (i) abundance and relatively low cost of the storage medium (rocks), (ii) the heat exchange by contact between the fluid (air) and the solid, which allows efficient heat transfer and thus small temperature differences between the two [24], (iii) the low conduction losses of the bed in the radial direction due to the void volume occupied by air and the large size of industrial systems, for which massive insulation is not needed, (iv) a fast response time [25], (v) scalability [26], (vi) wide temperature range of applicability, (vii) minimal degradation of materials during operation, (viii) no safety or environmental concerns, as no instable chemicals or corrosive materials are used. It should be noted that smaller systems, such as the one reported here, have a small ratio of rock volume to the volume of housing and insulation. Commercial HTTES systems are expected to be much larger, over 1000 times the mass of rocks, and the effects of heat losses to the walls and energy stored in the insulation and housing will be much lower. The principal disadvantage of rock-bed storage systems is the low roundtrip efficiency and the low energy density that can result in large structures and require relatively large swings in electricity price to be economical [27]. Another technological risk that may arise is represented by the thermal expansion of rocks during operating cycles which can result in long-term mechanical effects on the container (thermal 
ratcheting), which therefore must be carefully designed [28]. One of the major challenges of the technology is to achieve a uniform distribution of temperature and air flow to maximize charge and discharge efficiency.

Modelling of rock-bed storage systems dates back to 1929, when Schumann [29] proposed an analytical solution for the problem of thermal interaction between a flowing fluid and a porous medium for a step change of the inlet air temperature. Shitzer and Levy [27] provided an analytical solution for the problem of variable temperature of the inlet air to the storage system by first simplifying Schumann's solution, then applying Duhamel's theorem to these new expressions. Their experimental setup consisted of a vertical storage cylinder with two cones at the upper and lower extremities, in order to allow the flow to properly distribute before entering the porous medium in both charge and discharge configurations. Other pertinent modeling studies are based on the work originally done by Schumann and deal with 1D and 2D heat transfer models with two separate phases [30-31], and many models were developed for the temperature range 60$200^{\circ} \mathrm{C}$ employing oil, water or air as a working fluid [32-33]. Fewer studies analyzed the high temperature range, namely experimental testing and modeling of a packed bed of crushed steatite heated to $550^{\circ} \mathrm{C}$ [34] and of $\mathrm{ZrO}_{2}$ pellets up to $1000^{\circ} \mathrm{C}$ [35-36].

Design, fabrication, testing and heat transfer modelling of a pilot-scale rock bed was also proposed by Zanganeh [37] and Geissbülher [38], considering variable thermo-physical properties for both fluid and solid phases; focus was placed on the influence of radiation heat transfer inside the bed, and on the shape and orientation of the rock bed. In this study the packed bed had a truncated cone shape and was buried in the ground. From this setup a numerical heat transfer model was validated to solve the transient energy equations for the fluid and solid phases. Regarding the experimental section, focus was put on the evolution of efficiency, during charge and discharge cycles, at increasing number of operating cycles. Agalit [39] used a similar modeling approach and focused on developing a mathematical model with some modifications to the Zanganeh model: firstly, the working temperatures of the rocks was extended to $1000^{\circ} \mathrm{C}$ and the operating pressures to $10 \mathrm{bar}$; secondly, additional storage materials (ACW ceramics) besides natural rocks were studied; lastly, the volumetric heat transfer coefficient was calculated using a correlation presented by Coutier and Farber [40], which was derived from experimental results and was deemed more appropriate. The outcome of this test included a 1D heat transfer model with variable thermo-physical properties for both the rock and fluid domains and considerations on the radiative heat transfer between particles and between particles and surrounding walls.

A crucial topic in the study of packed bed is the estimation of friction factors and pressure drops, due to the economic consequences that this aspect implies in fan design. Particle shape and arrangement were found to have great influence, as initially studied by Ergun [41] and Shitzer and Levy [27], then numerically simulated by Zavattoni [42], and finally empirically investigated for rocks by Allen [43]. Shape and arrangement were also proved to affect heat transfer inside the bed, due to effects on thermal radiation, convection and axial conductivity. Correlations to predict pressure drop and heat transfer in packed beds were developed [44]. On the basis of these studies, investigations were carried out to define the costoptimum rock particle size and bed dimensions [45].

Apart from geometric considerations of the rock bed, the mineralogical composition and texture of the rocks have an influence on the efficiency of the system. The important points to consider include the number of different mineral phases, their spatial configuration (texture), the physical stability of individual minerals under repeated heating and cooling cycles, and importantly, their thermal capacity (i.e. heat capacity multiplied by their density) [46-47]. Furthermore, the thermal expansion of individual minerals has an effect 
on the stability of the rocks, while the overall expansion of the rock bed needs to be considered in the construction of the system.

The goal of this work is to present the system design and rock selection process and provide an experimental characterization of a lab-scale HTTES rock bed system. A horizontal flow orientation was investigated as the mechanical implementation is promising for upscaling and allows (i) a cheaper and less complex design of the piping systems with no structural solutions to protect the pipes from the weight of the stones; and (ii) a significant reduction in the excavation costs for integrating the rock bed into the ground. Several configurations of air flows were tested, with the main focus on defining how buoyancy affects the performance of the storage, mainly in terms of energy and exergy efficiencies during the charge phase and in the overall efficiency. Comparisons between different setups were performed. The effects of modifying valve configurations and the configuration of the rock bed were studied and the efficiency of each configuration is presented below.

\section{System Description}

\subsection{Rock selection}

The selection of rocks for this project was guided by two main constraints. First, the selection has to include rock types that contain minerals with high heat capacities. This allows a high capacity of energy storage for the system. The specific heat capacity of different minerals was compiled from literature data and from that list, potential rock types were identified. The second constraint was that these rocks should be readily available in different sizes and possible to ship to Denmark for a reasonable price, as this will be an important consideration for commercial systems. Because the shipping costs are generally similar to the cost of rock material, it makes most economic sense to source rocks from near the energy storage location and from sources with good shipping connections. In total nine different rocks types ranging in composition from ultramafic (dunite), to basaltic/gabbroic and granitic as well as a quartzite and magnetite concentrate were calorimetrically measured to determine their overall heat capacity (Table 1). Equally, their densities were determined because this together with the heat capacity controls the overall heat storage capacity for a given volume of rock. Several basalts coming from different quarries in Germany and Austria were tested, but their mineralogy and textures vary only a small amount, hence, their performance and properties were similar.

Table 1. Summary of the thermal properties of rock types that were considered. Average specific heat $\left(c_{p}\right)$ values are calculated over the temperature range $40-600{ }^{\circ} \mathrm{C}$.

\begin{tabular}{|r|l|l|l|l|l|l|l|}
\hline Nr. & Petrologic classification & Origin & $\begin{array}{l}\text { Suitable for } \\
\text { high } \\
\text { temperature }\end{array}$ & $\begin{array}{l}\text { Average } \\
c_{p}, \text { raw } \\
(\mathrm{J} / \mathrm{K} / \mathrm{g})\end{array}$ & $\begin{array}{l}\text { Average } \\
c_{p}, \text { after } \\
\text { heating } \\
(\mathrm{J} / \mathrm{K} / \mathrm{g})\end{array}$ & $\begin{array}{l}\text { Density } \\
(\mathrm{g} / \mathrm{cm} 3)\end{array}$ & $\begin{array}{l}\text { Average } c_{p} \\
\text { times } \\
\text { Density, } \\
\text { pre-heated } \\
(\mathrm{J} / \mathrm{K} / \mathrm{m} 3)\end{array}$ \\
\hline 1 & Magnetite & Sweden & Yes & 0.93 & 0.82 & $\begin{array}{l}4.68 \pm \\
0.23\end{array}$ & 3.8 \\
\hline 2 & Dunite & Norway & No & n/a & n/a & $\begin{array}{l}2.74 \pm \\
0.10\end{array}$ & n/a \\
\hline 3 & Ilmenit-norite/Gabbro & Sweden & Yes & 0.90 & 0.82 & $\begin{array}{l}2.82 \pm \\
0.28\end{array}$ & 2.2 \\
\hline 4 & Gabbro/norite & Sweden & Yes & n/a & n/a & $2.65 \pm$ & n/a \\
\hline
\end{tabular}




\begin{tabular}{|r|l|l|l|l|l|l|l|} 
& & & & & 11 & \\
\hline 5 & Anorthosite & Norway & Yes & 1.08 & 0.95 & $\begin{array}{l}2.71 \pm \\
0.09\end{array}$ & 2.6 \\
\hline 6 & Diabase & Sweden, Finland & Yes & 1.13 & 0.96 & $\begin{array}{l}2.75 \pm \\
0.09\end{array}$ & 2.6 \\
\hline 7 & Basalt & Germany, Austria & Yes & 1.08 & n/a & $\begin{array}{l}3.09 \pm \\
0.39\end{array}$ & n/a \\
\hline 8 & Quartzite & Sweden & No & n/a & n/a & $\begin{array}{l}2.66 \pm \\
0.07\end{array}$ & n/a \\
\hline 9 & Granite & Denmark & No & 1.18 & n/a & n/a & n/a \\
\hline
\end{tabular}

To test the physical stability of the rocks under high temperatures, several pieces of all samples were heated in a muffle oven to $600^{\circ} \mathrm{C}$ and $800^{\circ} \mathrm{C}$ in different experiments with a heating rate of about $20^{\circ} \mathrm{C} / \mathrm{min}$. The samples were kept at the peak temperature for 47 hours $\left(600^{\circ} \mathrm{C}\right)$ and 64 hours $\left(800^{\circ} \mathrm{C}\right)$, respectively. Subsequently, they were taken out and left to cool at room temperature. Additional cycling experiments where performed in which the samples were heated 5 times to $600^{\circ} \mathrm{C}$ and held at the high temperature for one hour before they were cooled to room temperature and held for 30 mins before the next heating cycle. Samples were macroscopically and microscopically inspected using thin sections and a polarization microscope before and after the heating experiments. Micro- X-ray fluorescence spectroscopy and electron microprobe analyses were performed to determine potential chemical changes in the mineral phases. The main signs of alteration of all rocks were slight to pronounced reddening due to oxidation of iron in the minerals.

The results showed that granite, dunite, and the tested quartzite are unsuitable for a high temperature thermal storage system. The granite contains a large proportion of hydrous minerals (e.g., biotite) which are not stable. Similarly, dunite, consisting mainly of olivine, showed strong signs of oxidation and became very friable and disintegrated during thermal cycling. The quartzite included interstital phases that broke down at high temperature and weakened the rock. Gabbroic and basaltic samples performed well. Nevertheless, the best candidate for the laboratory rock bed in terms of thermal capacity and physical stability is the magnetite concentrate (which will be the subject of future studies). However, magnetite posed one practical challenge, which was that small magnetite particles tended to become magnetized and form a dust layer over the entire rock that was difficult to remove. The choice of rock for the initial tests of the pilot HTTES described here was a diabase from South Sweden. It showed good performance in the laboratory heating tests, it is readily available in Denmark and can be purchased in a range of sizes. It contains about $70-80 \%$ plagioclase, 20 $30 \%$ pyroxene and minor $(<1 \%)$ biotite and oxides.

\subsection{System Description}

The rock bed occupies a volume of approximately $1.5 \mathrm{~m}^{3}$ and was designed for flexible characterization and testing of different HTTES configurations. The flow orientation was chosen horizontal for practical reasons, as explained in the introduction, and the system is illustrated in Figure 1. The rock bed was surrounded by an insulation layer and then enclosed in an outer shell of $4 \mathrm{~mm}$ thick steel, which guaranteed an air tight inner environment thanks to a high-temperature sealing. The inner insulation consisted of two $100 \mathrm{~mm}$ thick layers of Skamol Super-ISOL thermally insulating bricks separated by $3 \mathrm{~mm}$ of Superwool 607 plus paper on the bottom and sides. Hard insulation was required on the bottom and sides to structurally support the rock bed. A final $13 \mathrm{~mm}$ thick layer of Superwool 607 HT blanket was directly in contact with the rocks to give a partially compliant wall on the boundary of the rock bed, with the goal of reducing the porosity at the walls, 
which could create preferential air flow channels and generate a wall effect [48]. The top of the rock bed was insulated with $200 \mathrm{~mm}$ of soft thermal insulation (Superwool 607 HT Blanket). An additional $100 \mathrm{~mm}$ layer of soft insulation was installed on the outside surface of the steel housing. Two vertical stainless steel grids with $6 \mathrm{~mm}$ holes contained the rocks at the hot and cold ends and separated them from entrance and exit regions for the distribution and collection of the air flow. The flow areas before and after the rock bed were also insulated with two $100 \mathrm{~mm}$ thick layers of Skamol Super-ISOL bricks separated by $3 \mathrm{~mm}$ of Superwool 607 plus paper. A description of the rock bed design is given in Figure 2.

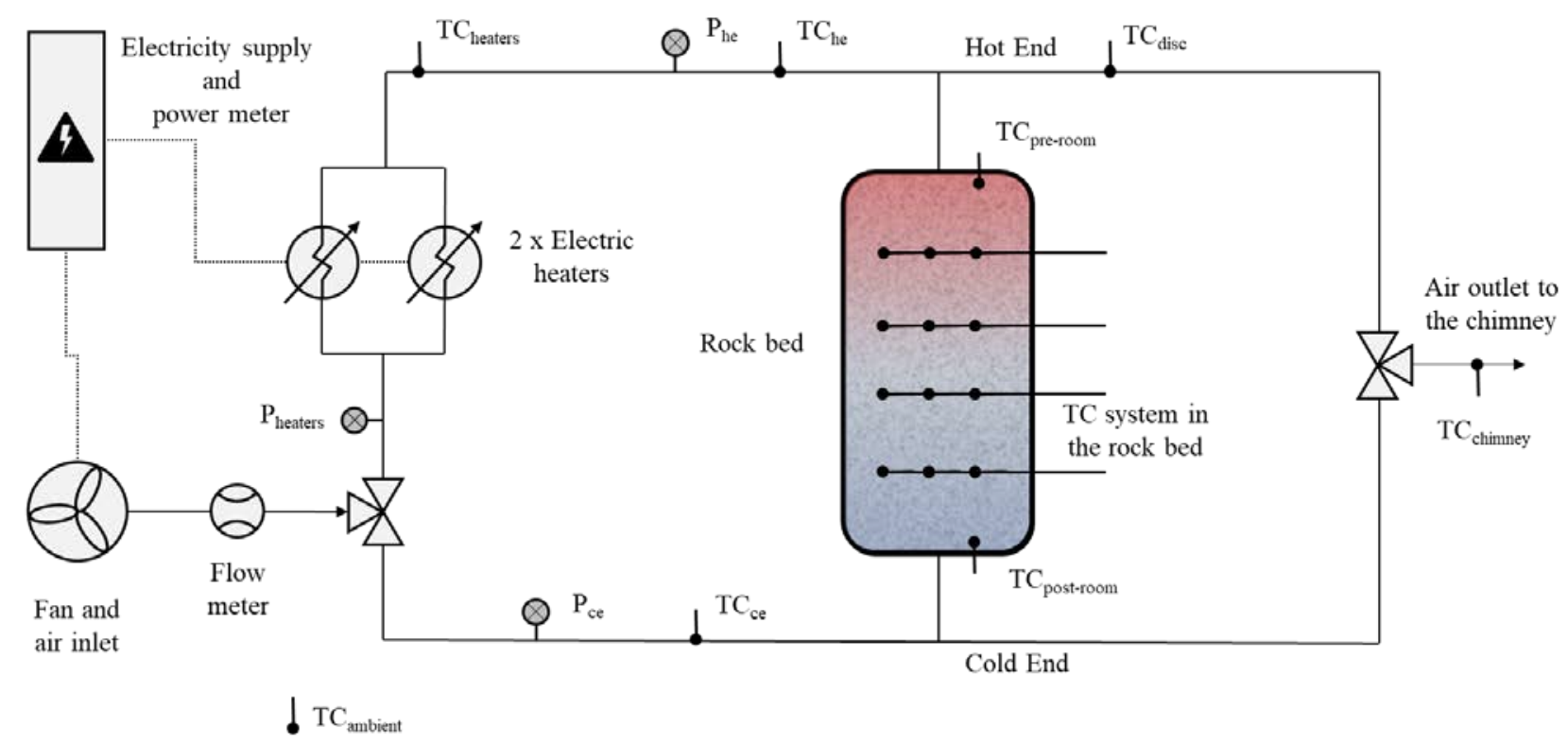

Figure 1. Schematic of the experimental setup showing data acquisition locations, such as air flow meter and pressure gages, valve locations and air flow schematic. 


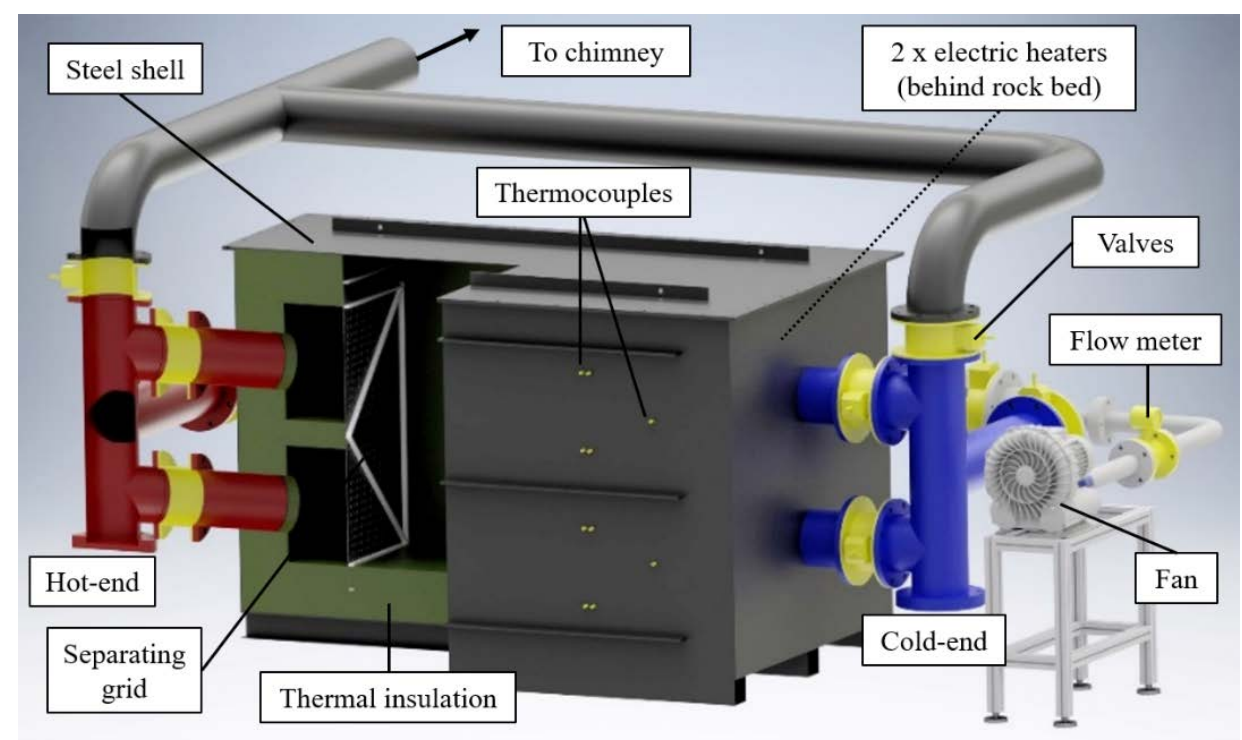

Figure 2. CAD model of the HTTES system standard configuration with a section view of the hot end. Major components such as valves and the fan are also shown. Separating layers used in the lasagna configuration are not shown.

Two inlet and two outlet ports connected to dedicated on/off valves at both the hot and cold ends were designed to control the inlet and outlet air flows and make several flow configurations possible. Stainless steel pipes with a diameter of $200 \mathrm{~mm}$ insulated on the outside connected the rock bed to the fan and heaters. The integrated system comprising auxiliary components and data acquisition system is illustrated in Figure 1. A system of valves allowed for reversing the flow to perform both charge and discharge cycles with the same fan. Two $15 \mathrm{~kW}$ heaters connected in parallel, each connected to a PID temperature controller, heated the air to the desired temperature. A detailed summary of the components is given in Table 2 and a photograph of the test setup is shown in Figure 3.

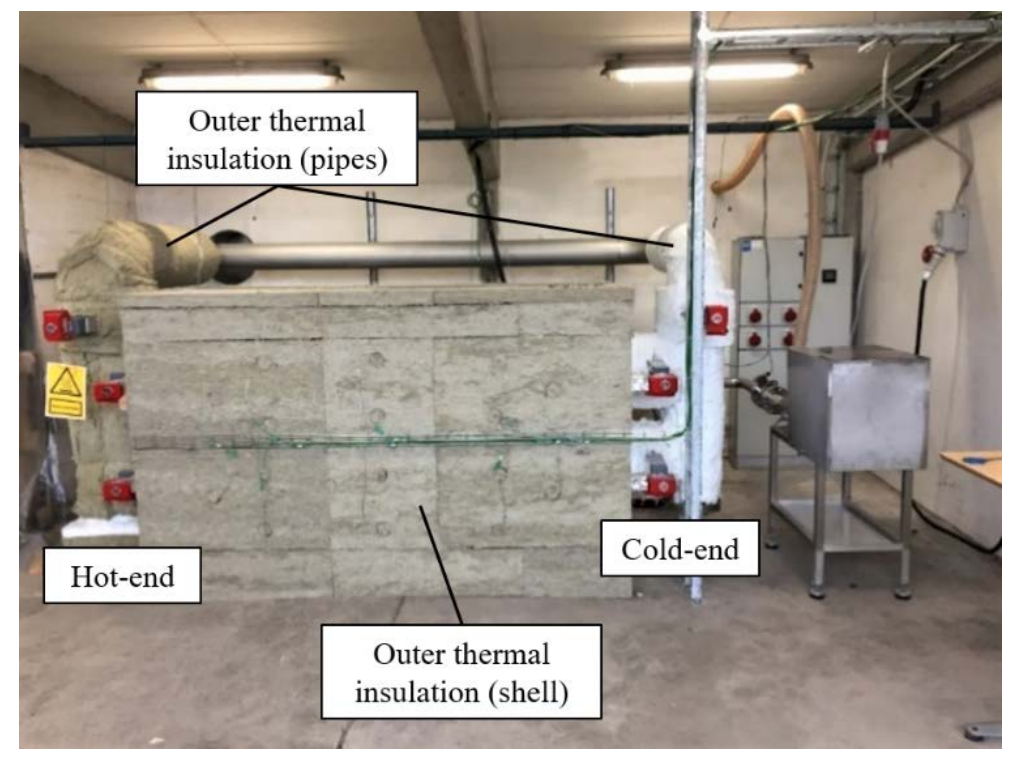

Figure 3. A photo of the equipment from the front view with insulation installed. Thermocouple wires leaving the side of the rock bed can be seen along with the valve actuators. 
During charge, the fan blew ambient air through the electric heaters and further into the rock bed from the hot end, where it progressively exchanged heat with the rocks. Exhaust air left the system from the cold end and finally flowed to the chimney. During discharge, the fan blew outdoor air into the rock bed from the cold end to progressively recover the stored heat. A hot air stream left the bed from the hot end to the chimney.

A flow meter measured the air flow from the fan before it entered the heaters, while pressure gages monitored the pressure across the system. A system of temperature sensors was installed to measure the air temperature at several locations throughout the setup, such as at the fan outlet, the heater outlet, the hot end, the cold end, and the chimney. These temperatures were used to calculate energy balances, calculate the input and output energy fluxes and characterize the heat losses. Several thermocouples were also installed inside the rock bed to monitor the rock and air temperatures and to re-construct the temperature distribution inside the rock bed. A more detailed explanation of the temperature measurements in the rock bed is given in section 3.1. Finally, an additional meter recorded the electrical energy that was supplied to the fan and to the heaters. The maximum charging capacity of the system was $30 \mathrm{~kW}$, which is the maximum total heater power. The thermal energy storage capacity of the system was estimated to be $450 \mathrm{kWh}$ for a storage temperature of $600^{\circ} \mathrm{C}$ as shown in Eq. 3 .

$$
C_{t h}=(1-\varepsilon) \cdot V_{\text {storage }} \cdot \rho_{r} \cdot \int_{T_{a m b}}^{T_{\text {storage }}} C_{r}(T) \cdot d T
$$

Where $C_{\text {th }}$ is the thermal capacity of the storage, $\varepsilon$ is the porosity of the rock bed calculated to be $0.45, V_{\text {storage }}$ is the volume of the storage occupied by the rocks $\left(1.5 \mathrm{~m}^{3}\right), \rho_{r}$ is the density of the rocks measured as 3007 $\mathrm{kg} / \mathrm{m}^{3}, \quad c_{r}$ is the specific heat of the rocks, $T_{\text {storage }}$ is the maximum storage temperature, $600^{\circ} \mathrm{C}$ for this case, and $T_{a m b}$ is the inlet cold air temperature, assumed $20^{\circ} \mathrm{C}$ for this work. The contribution of the air to the storage capacity is considered negligible. The rocks were sieved in the range $16-22 \mathrm{~mm}$, mean that the rocks used passed through a grid with $16 \mathrm{~mm}$ openings but were caught by a grid with $22 \mathrm{~mm}$ openings. Because the rocks have an irregular shape, some rocks were between 16-22 $\mathrm{mm}$ in one direction but longer in another direction. 
Table 2 List of the main components used in the integrated system.

\begin{tabular}{|c|c|c|c|c|}
\hline Component & No. & Description & Manufacturer & Model No. \\
\hline Fan & 1 & $\begin{array}{l}\text { Centrifugal fan max } 325 \mathrm{~m}^{3} / \mathrm{h} \text {, max } \\
30000 \mathrm{~Pa}\end{array}$ & Becker & SV 300/1 \\
\hline Heaters & 2 & $\begin{array}{l}15 \mathrm{~kW} \text { electric heaters assembled in } \\
\text { parallel }\end{array}$ & Leister & LE $10000 \mathrm{HT}$ \\
\hline $\begin{array}{l}\text { Heater } \\
\text { controller }\end{array}$ & 1 & PID heater controller (On/off control) & Omron & E5DC \\
\hline Flow meter & 1 & $\begin{array}{l}\text { Turbine flow meter } 15-200 \text { m3/h, 1.5\% } \\
\text { O.R. accuracy }\end{array}$ & Bell & $\begin{array}{l}\text { GFT-A-100-S(X)-S- } \\
\text { S-N }\end{array}$ \\
\hline Pressure gages & 3 & $\begin{array}{l}\text { Low pressure transducers: } 2 \times 4000 \mathrm{~Pa} \\
\text { and } 1 \times 6000 \mathrm{~Pa}, 0.50 \% \text { F.S.O. }\end{array}$ & DMP & 343 \\
\hline $\begin{array}{l}\text { Temperature } \\
\text { sensors }\end{array}$ & 37 & $\begin{array}{l}\text { Type } \mathrm{K} \text { thermocouples with stainless } \\
\text { steel shielding, } \pm 1.5^{\circ} \mathrm{C}\end{array}$ & RS & $787-7863$ \\
\hline Energy meter & 1 & $\begin{array}{l}\text { Rated voltage } 230 \mathrm{~V} \pm 10 \% \text {, nominal } \\
\text { frequency } 50 \mathrm{~Hz} \pm 2 \% \text {, average } \\
\text { maximum permissible error }+0.1 \%\end{array}$ & Kamstrup & $382 \mathrm{Mx} 7$ \\
\hline DAQ & 1 & $\begin{array}{l}8 \text { channels for measuring flow and } \\
\text { pressures. }\end{array}$ & $\begin{array}{l}\text { National } \\
\text { Instruments }\end{array}$ & NI $9203-4-20 m A$ \\
\hline DAQ & 1 & $\begin{array}{l}48 \text { channels to acquire signal from } \\
\text { thermocouples }\end{array}$ & $\begin{array}{l}\text { National } \\
\text { Instruments }\end{array}$ & NI $9213- \pm 78 \mathrm{mV}$ \\
\hline
\end{tabular}

\section{Experimental Procedure and Figure of Merit}

The performance of the rock bed as a high temperature thermal energy storage unit was studied and quantified through different figures of merit and criteria. These criteria allowed the comparison of different operating conditions and are aimed at improving overall storage efficiency.

\subsection{Operating conditions}

The rock bed was characterized during the processes of charge, discharge and storage. The operating conditions were varied to study how operating conditions affected performance and to evaluate the influence of buoyancy forces on flow and temperature distributions. The operating conditions that were varied are:

- Charge rate: different charge rates, which resulted in different air flow rates, were tested to investigate the effect on the temperature distribution inside the rock bed. Tests were conducted at a slow flow rate (around $75 \mathrm{Nm}^{3} / \mathrm{h}$ ) which is equivalent to a charge capacity of approximately $17 \mathrm{~kW}$; and at a fast flow rate (around $130 \mathrm{Nm}^{3} / \mathrm{h}$ ) that corresponds to a charge capacity of approximately 27 $\mathrm{kW}$. The testing of two different charge rates allowed evaluating the effect of buoyancy forces on the 
temperature distribution and on the horizontal flow inside the rock bed, given two different air flow speeds and inertias. In order to obtain comparable total energy inputs to the rock bed for all charging tests, a duration of 26 hours was chosen for the $17 \mathrm{~kW}$ charge rate, while a duration of 16 hours for the $27 \mathrm{~kW}$ charge rate. In this way a similar total energy input to the system of about $435 \mathrm{kWh}_{\text {th }}$ was used to charge the bed. The air temperature at the inlet of the rock bed was between 585 and $605^{\circ} \mathrm{C}$ for all experiments. The difference was due to slightly different heat losses in the inlet pipes, due to the different flow speeds, heat transfer coefficients and environmental conditions. Discharge cycles were all performed at a fast rate, with an air flow of approximately $140 \mathrm{Nm}^{3} / \mathrm{h}$. Changes in outdoor conditions altered the discharge cycle as colder air was used to discharge the bed during some parts of the year compared to others.

- Inlet and outlet valve configurations: different flow patterns inside the rock bed were possible due to the two valves at the both hot and cold ends. Valves were tested open, partially closed or completely closed according to the configurations reported in Table 3. These tests were performed to find the optimal flow distribution inside the rock bed that could optimize the efficiency of the charge and discharge cycles.

Table 3 List of tested valves configurations.

Valve configuration Label

\begin{tabular}{ll}
\hline All valves fully open & AO \\
\hline Bottom inlet open, top inlet closed \\
Bottom outlet open, top outlet closed & BIBO \\
\hline $\begin{array}{l}\text { Top inlet open, bottom inlet closed } \\
\text { Top outlet open, bottom outlet closed }\end{array}$ & TITO \\
\hline $\begin{array}{l}\text { Either top or bottom valves adjusted to equalize } \\
\text { temperature in the flow distributors }\end{array}$ & VREG \\
\hline
\end{tabular}

- Division of the rock bed in horizontal sections: horizontal thermally insulating layers were installed between layers of rocks with the goal of limiting vertical air flow due to buoyancy effects with respect to the rock bed without layers (standard design, shown in Figure 2). The layered layout was named the lasagna design for this work. Three thermally insulating layers were introduced to split the bed into 4 horizontal layers. A thicker air-tight separating layer was inserted in the middle of the bed to make the two top rock layers independent from the two bottom ones. Figure 4 shows an illustration of the lasagna configuration along with locations of the thermocouples in the bed. 


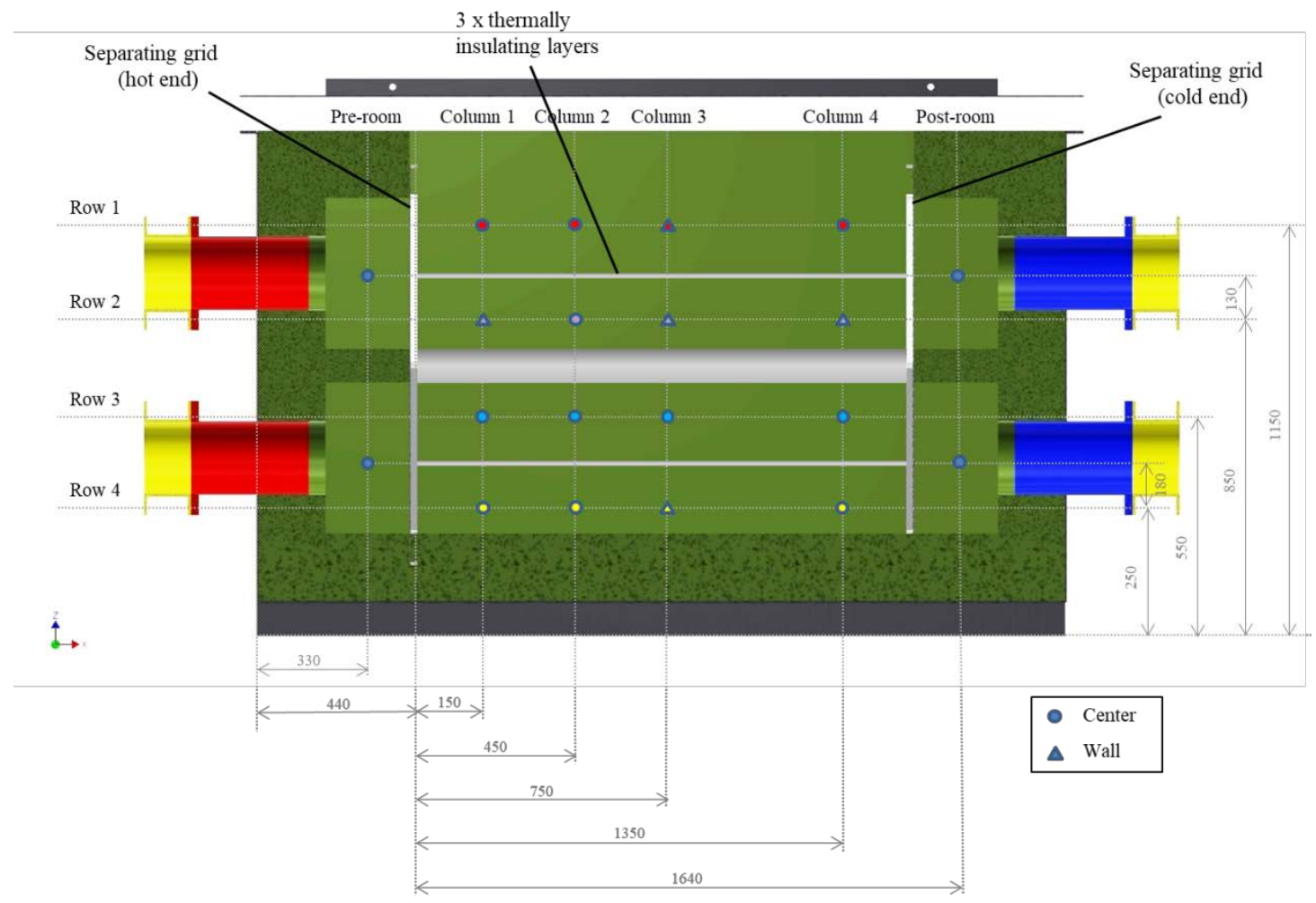

Figure 4. Thermocouple positions and inner structure of the rock bed for the lasagna configuration. Most thermocouples are located at the center line of the bed while some are near the wall. The thermocouple wires exiting the side of the rock bed housing can be seen in Figure 3.

\subsection{Figures of merit}

In order to evaluate the performance of the system and to compare different experiments, different figures of merit were defined. A system of thermocouples measured the temperature in some crucial locations inside the rock bed (Figure 4). These measurements were then used in a 3D temperature reconstruction tool that gave a more detailed temperature distribution inside the rock bed. The reconstruction tool also allowed having a finer estimate of the stored energy and exergy during the charge and discharge cycles. The specific internal energy is given by:

$$
u=\int_{T_{r e f}}^{\bar{T}} c_{p}(T) d T
$$

where $T_{r e f}$ is the reference temperature at which internal energy is considered zero. This calculation was performed for all the elements in which the rock bed was discretized, as it will be described later, after the subtraction of the specific internal energy at ambient conditions. The exergy is given by:

$$
\begin{aligned}
& b=u-T_{a m b} s \\
& s=\int_{T_{r e f}}^{\bar{T}} c_{p}(T) \frac{d T}{T}
\end{aligned}
$$

where $s$ is the specific entropy and $b$ the specific exergy. The same considerations made for the internal energy are valid also for the entropy and exergy. The specific air enthalpy is calculated as: 


$$
h=\int_{T_{r e f}}^{\bar{T}} c_{p}(T) d T
$$

Heat losses in the rock bed were lumped into three areas: losses from the inlet pipe, outlet losses and heat losses through the walls. The inlet pipe losses were calculated as the enthalpy difference between the hot air flow upstream and downstream of the inlet pipe, by means of the temperature data logged by thermocouples in those spots and thermo-physical temperature-dependent properties of air provided by [49]. Outlet losses are calculated as the enthalpy difference between the air flow exiting the rock bed through outlet pipe and the outer environment. They represent the amount of energy that enters the rock bed but is not stored. Wall losses are modelled as 1D thermal conduction and radiation from the air inside the rock bed through the insulation layers and finally to ambient. The heat transfer coefficient characterizing heat conduction, convection and radiation at the inner walls was calculated considering [37], [50] and [51]. Experimental validation of the wall losses model is provided by means of temperature measurements on the external surface of the rock bed performed with an IR camera. Model results always fall within the range of uncertainty of the experimental measurement. Temperature results for the intermediate insulation layers are used for the estimation of the heat storage in the thermal insulation, which is then verified by means of an overall energy balance considering the energy provided by the heater and all the heat losses. Results denote an underestimation in the order of $5 \%$ of the heat stored when calculated with the first method with respect to the energy balance. This mismatch is likely due to the approximation of the heat transfer coefficients at the inner walls with empirical correlations, as well as to the approximation of the material properties, in the 1D heat loss model. Furthermore, the experimental temperatures and flows that were input to the model, also subject to uncertainty, could have contributed to the mismatch between the two methods.

The main figures of merit emerging from the these parameters are first law charging and roundtrip efficiencies $\left(\eta_{C H}\right.$ and $\left.\eta_{R T}\right)$ and second law charging and roundtrip efficiencies $\left(\eta_{I I, C H}\right.$ and $\left.\eta_{I I, R T}\right)$, i.e. the ratio, respectively, between energy (exergy) stored in the rock bed and the provided amount, and between recovered and provided energy (exergy). In addition to this, the state of charge (SOC) is considered, calculated as the stored energy divided by the maximum energy storable in the facility of $450 \mathrm{kWh}$.

$$
\begin{gathered}
\eta_{C H}=\frac{\int_{V}(1-\varepsilon) \cdot \rho_{r} \cdot\left(u_{r}\left(T_{t_{0}}\right)-u_{r}\left(T_{t_{\text {end }}}\right)\right) d V}{E_{H}+E_{\text {fan }}} \\
\eta_{I I, C H}=\frac{\int_{V}(1-\varepsilon) \cdot \rho_{r} \cdot\left(b_{r}\left(T_{t_{0}}\right)-b_{r}\left(T_{t_{\text {end }}}\right)\right) d V}{E_{H}+E_{\text {fan }}} \\
\eta_{R T}=\frac{\int_{t_{0}}^{t_{\text {end }}} \dot{m}_{f} \cdot\left(h_{f}\left(T_{\text {recov }}\right)-h_{f}\left(T_{\text {amb }}\right)\right)}{E_{H}+E_{\text {fan }}} \\
\eta_{R T}=\frac{\int_{t_{0}}^{t_{\text {end }}} \dot{m}_{f} \cdot\left(b_{f}\left(T_{\text {recov }}\right)-b_{f}\left(T_{a m b}\right)\right) d t}{E_{H}+E_{\text {fan }}}
\end{gathered}
$$

Where $E_{H}$ and $E_{f a n}$ are the electric energy input to the heater and to the fan, respectively, $\dot{m}_{f}$ is the discharge air mass flow rate, $h_{f}$ is the air specific enthalpy, and $b_{f}$ is the air specific exergy. $T_{\text {recov }}$ and $T_{a m b}$ are the 
recovered air temperature (at $\mathrm{TC}_{\text {disc }}$ in Figure 1) and the inlet air temperature, respectively. Times $t_{0}$ and $t_{\text {end }}$ correspond to the start and the end of the analyzed cycle. The subscripts $r$ and $f$ refer to rocks and air, respectively.

It is important to note that the energies considered in the charge and roundtrip expressions are calculated with different approaches. The charge efficiency equation considers only the energy stored in the rocks and ignores heat stored in the insulation and other components. However, for a smaller setup as the one tested in this work, the heat stored outside the rock bed can be significant. The roundtrip efficiencies, instead, are defined as the heat recovered by the discharge air flow calculated as the integral over time of the air enthalpy difference between outlet and inlet. The roundtrip efficiency therefore accounts for the heat stored in the insulation and other external equipment, providing the overall efficiency of the storage unit. The difference between these two calculation methods can result in higher roundtrip efficiencies than charge efficiencies.

\subsection{Three-dimensional bed reconstruction tool}

In order to calculate the energy stored in the rock bed at any given time with a fine resolution, it is necessary to interpolate the measured temperatures in three dimensions over the entire bed. However, there are not enough thermocouple measurements to accurately recreate the temperature profile in the bed through simple linear interpolation, especially since the ends of the bed require extrapolation. A tool based on a 1D porous media model, which has been previously reported [52], was used to build a full 3D temperature profile from the available experimental temperature measurements. The governing equations used in the model for the air (the fluid) and the rocks (the solid) are given below.

$$
\begin{gathered}
\frac{\partial}{\partial x}\left(k_{d i s p} \frac{\partial T_{f}}{\partial x}\right) A_{c}-\dot{m}_{f} c_{f} \frac{\partial T_{f}}{\partial x}-\frac{N u k_{f}}{d_{h}} a_{s} A_{c}\left(T_{f}-T_{r}\right)+\left|\frac{\partial P}{\partial x} \frac{\dot{m}_{f}}{\rho_{f}}\right|=\rho_{f} A_{c} \varepsilon c_{f} \frac{\partial T_{f}}{\partial t} \\
\frac{\partial}{\partial x}\left(k_{s t a t} \frac{\partial T_{r}}{\partial x}\right) A_{c}+\frac{N u k_{f}}{d_{h}} a_{s} A_{c}\left(T_{f}-T_{r}\right)=A_{c}(1-\varepsilon) \rho_{r} c_{r} \frac{\partial T_{r}}{\partial t}
\end{gathered}
$$

where $k, \rho$, and $c$ are the thermal conductivity, density, and specific heat. $A_{c}, d_{h}, a_{s}$, and $\varepsilon$ are the cross sectional area, hydraulic diameter, volumetric specific area, and porosity. The fluid flow direction is $x$, and $t$ and $\dot{m}$ are time and the fluid mass flow rate. The subscripts $f$ and $r$ represent fluid and rocks, respectively. The thermal conductivity due to fluid dispersion is $k_{\text {disp }}$, static thermal conductivity is $k_{\text {stat }}$, and the pressure drop is $\partial P / \partial x$. The energy terms in the fluid equation represent the axial thermal conduction attributed to the fluid, the energy flux from the fluid flow, heat transfer to the rock bed, pump work dissipation and thermal energy storage, from left to right. The terms in the solid equation represent axial thermal conduction attributed to the rocks, heat transfer to the fluid and thermal storage in the rocks, from left to right. The timedependent equations are solved using implicit time steps over an equally spaced time grid, and gives timedependent temperatures of the rock material and air in the rock bed as well as the temperature of the air exiting the rock bed. A detailed description of the model and numerical technique is given in the supplementary material. All following temperature profiles presented are estimated using this technique in order to better visualize the results and improve the temperature resolution for calculating energy stored in the bed.

\section{Results and discussion}

Results of the present work include charge and discharge phase characterizations and roundtrip test comparisons. In each case the goal was to focus on specific processes rather than real world operating 
conditions. The charge phase was studied by starting each charge process from a fully discharged bed, the discharge process was studied by starting each cycle from a baseline charge and the round trip results were also started from a fully discharge condition in each case. The results for each process are presented below. All results presented in this work as well as additional experiments run as part of the project can be accessed at [53]. The results include all data collected on the experimental setup for each experiment. An analysis of the propagation of the uncertainty of measurement in the calculations was also performed, resulting in an average impact on the final efficiency results around $\pm 1 \%$.

\subsection{Charge phase results}

Each charge test was started from a fully discharge state, meaning the bed was discharged for over 24 hours before and experiment was started. This resulted in a starting bed temperature that was approximately the average outdoor temperature over the last day. Charging was carried out at two flow rates, with two corresponding heater powers: fast (27 kW) and slow (17 kW). Charging was performed for a range of valve configurations for both the open and lasagna bed designs. Each charge cycle was designed to give approximately the same integrated energy influx to the rock bed. Fast charge cycles lasted 16 hours while slow charge cycles lasted 26 hours. Table 4 and Table 5 report the charge efficiencies and other relevant parameters for the charge cycles at fast and slow charging rates. These results are supported and analyzed with the aid of the 3D temperature reconstructions. For the standard design with all valves fully open (AO), the time dependence for the first 16 hours of test of the selected temperature measurements for both the fast and slow charge are shown in Figure 5. In the figure, thermocouple columns 1, 3 and 4 in all four rows shown in Figure 4 are plotted to show the temperature breakthrough curves at a total of 12 locations in the rock bed. From the figure it can be seen that the fast charge results in a faster heating of the bed and in a steeper temperature gradient, seen as a smaller difference in the temperature between the top and the bottom of the bed. The difference in temperature profiles is most evident in the lowest row of thermocouples shown in Figure 5. This difference can be attributed to the longer cycle time of the slow charge, which gives a longer time for buoyancy effects to occur. The poorer temperature distribution in the bed during a slow charge results in more energy leaving the bed in the form of hot air from the upper outlet valve, hence in lower charging efficiency. The trend that there is a larger temperature gradient in the vertical direction for the slow charge rate is the same for all tests conducted and therefore only $17 \mathrm{~kW}$ tests are reported in detail below. Fast charge temperature profiles are given in the supplementary material. 


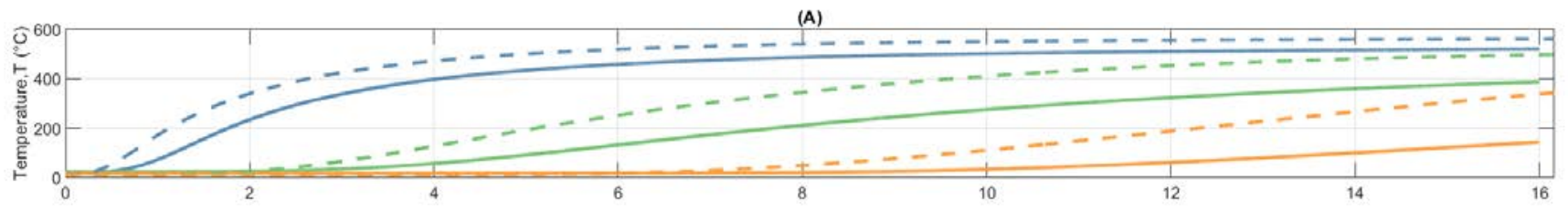

(B)

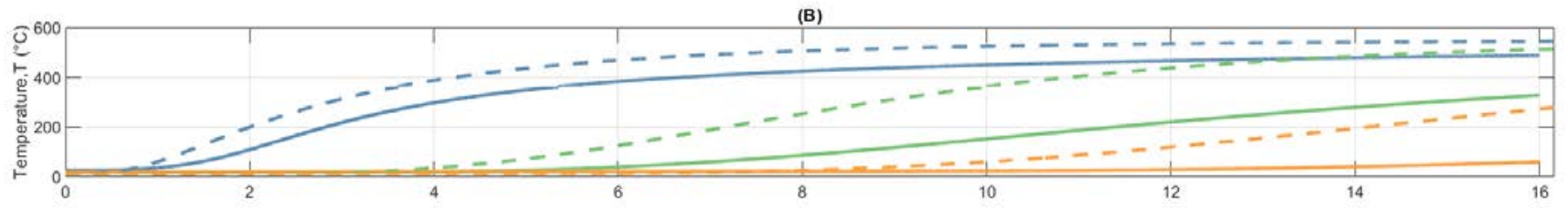

(C)
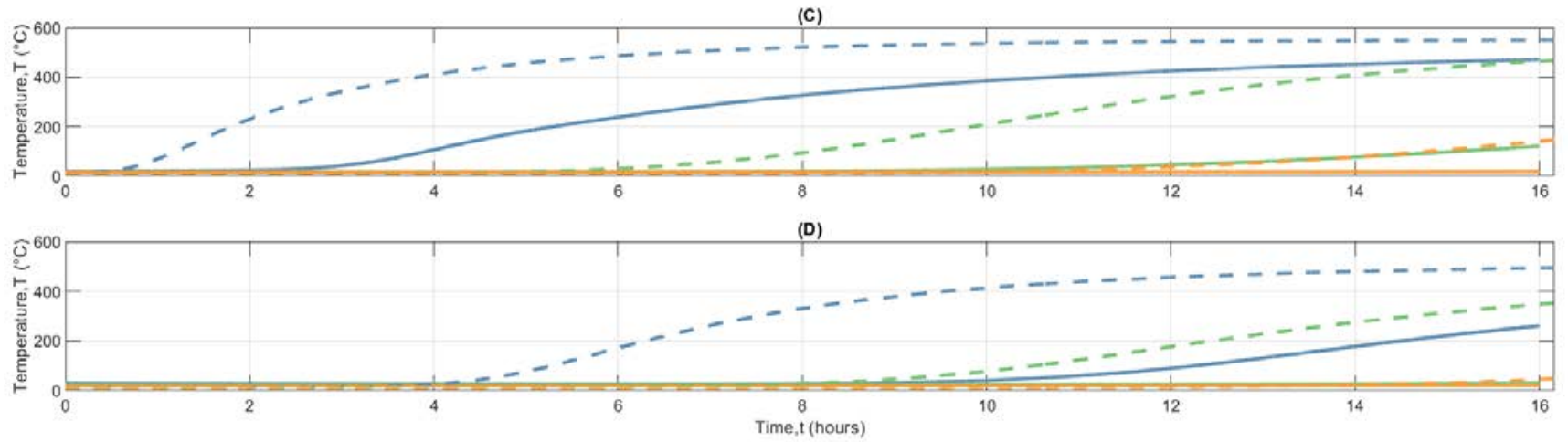

Figure 5. Temperature as a function of charge time for the standard design AO for all four rows of thermocouples shown in Figure 4. A: top layer (Row 1); B: middle-upper (Row 2); C: middle-lower (Row 3); D: bottom (Row 4). Solid lines: 17 kW input test; dashed lines: $27 \mathrm{~kW}$ input. Blue line: hot end; green: center; orange: cold end.

By changing the valve configuration to BIBO, the hot air flow is forced to enter and leave the rock bed from the lower valves, and buoyant forces are used to heat the upper levels of rock that are not exposed to air flow as directly. Hence, the temperature distribution in the vertical direction is better compared to AO. This results in lower outlet losses, but also in hot spots near the inlet, which can cause regions near the hot end to experience higher heat losses.

Adding horizontal insulation layers, the lasagna design, prevents vertical air flow and reduces temperature maldistribution caused by buoyancy. As shown in Figure 6(c-d) the lasagna configuration therefore results in the most uniform temperature distribution in the vertical direction, with a smaller difference in temperature from the top of the rock bed to the bottom. Especially at the hot end, the lasagna design has higher temperatures at the bottom of the bed compared to the standard design. It can however be seen that there is still a large temperature gradient in the vertical direction because the air flow is able to stratify in the pre-rooms before it enters the rock bed. The performance of the lasagna configuration can be further improved by adjusting the valves to give a more even air flow distribution to the upper and lower sections of the bed. This was achieved by partially closing the upper valves until the temperature in the upper and lower pre-rooms were approximately equal. It was observed that the air flow still stratifies inside the prerooms and the upper rock layer connected to each pre-room had a higher temperature than the lower rock layer. 3D temperature reconstructions of the rock bed are reported in Figure 6 for tests at $17 \mathrm{~kW}$. 


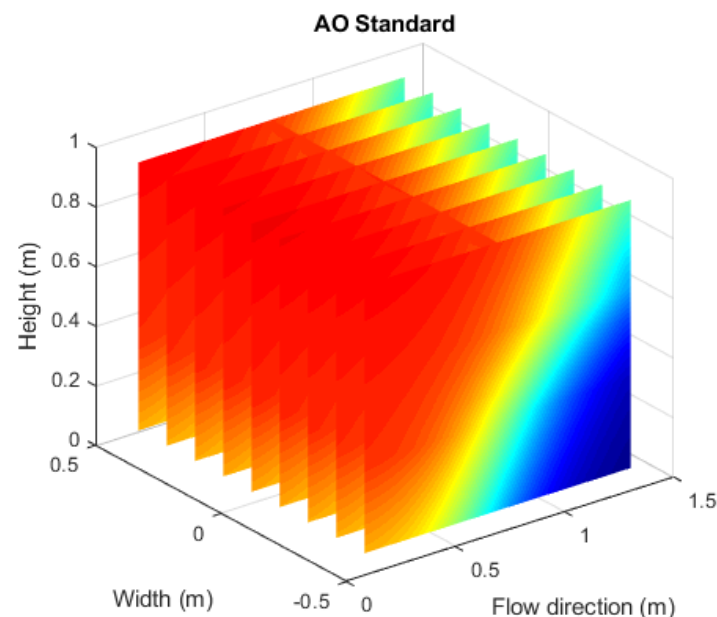

(a)

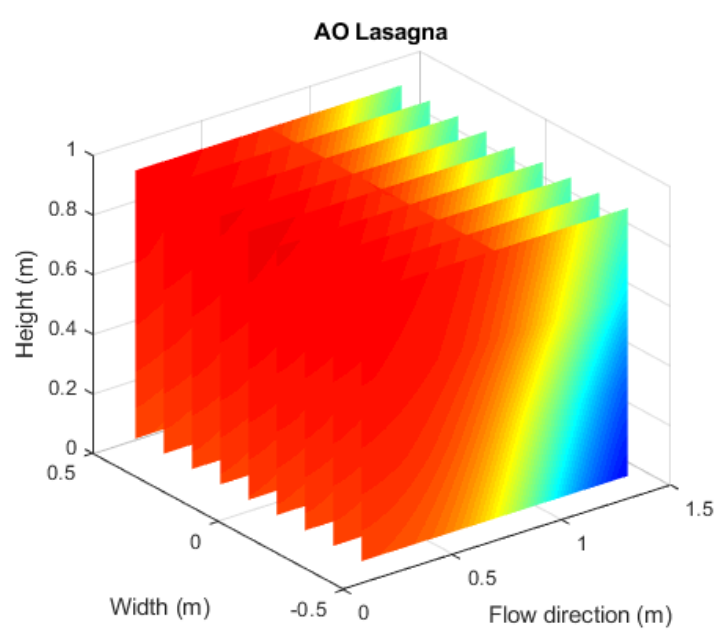

(c)

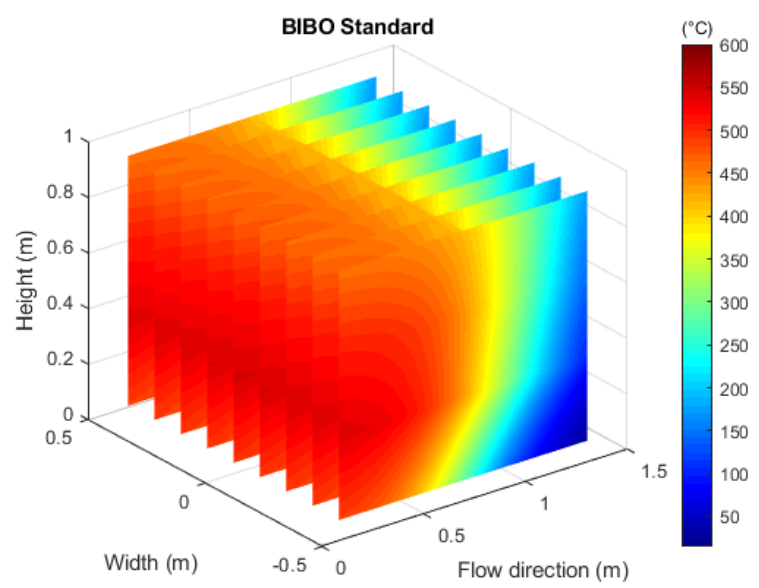

(b)

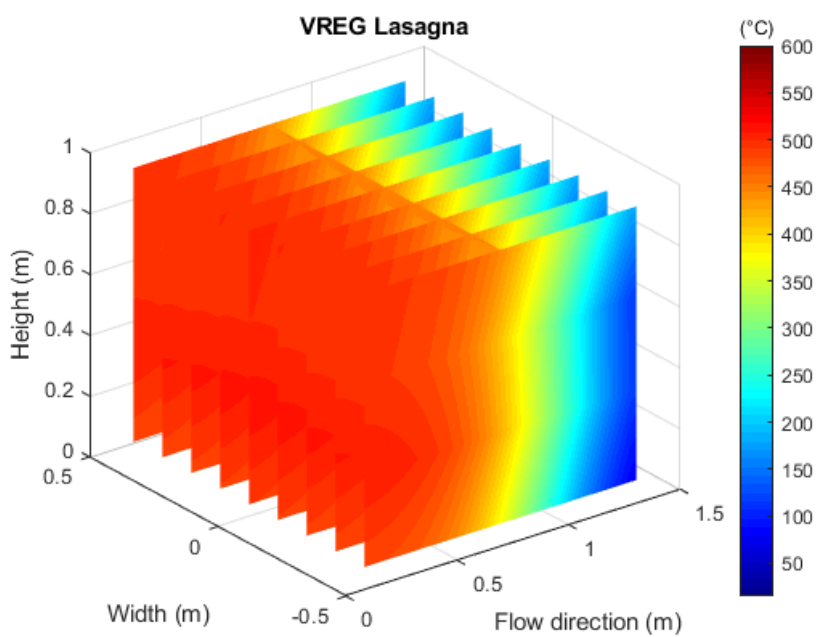

(d)

Figure 6. Three-dimensional temperature reconstruction of the rock bed for tests at $17 \mathrm{~kW}$ charge rate for (a) AO standard, (b) BIBO standard, (c) AO lasagna, and (d) VREG lasagna.

Results for the $27 \mathrm{~kW}$ tests are reported in Table 3. The table shows that the better temperature distribution shown for the lasagna configuration results in lower outlet losses, hence in higher charging efficiency values compared to the standard design.

Table 4. Perfomance summary for charge cycles at $27 \mathrm{~kW}$ for the four configurations tested.

Test

$\eta_{C H}(\%)$
$\eta_{I I, C H}(\%)$
Outlet losses

(kWh)

\begin{tabular}{cccc}
\hline Standard AO & 61.61 & 24.90 & 21.66 \\
Standard BIBO & 63.43 & 25.91 & 15.02
\end{tabular}




$\begin{array}{cccc}\text { Lasagna AO } & 68.68 & 27.15 & 14.32 \\ \text { Lasagna VREG } & 72.23 & 28.61 & 12.39\end{array}$

As shown in Table 4, outlet losses are higher for the standard configuration due to the hot air moving faster along the top of the rock bed. Outlet losses as a function of time for fast charge tests for different configurations are presented in Figure 7. The outlet temperature for the standard configuration with all valves open clearly increases faster the other configurations, indicating high outlet losses.

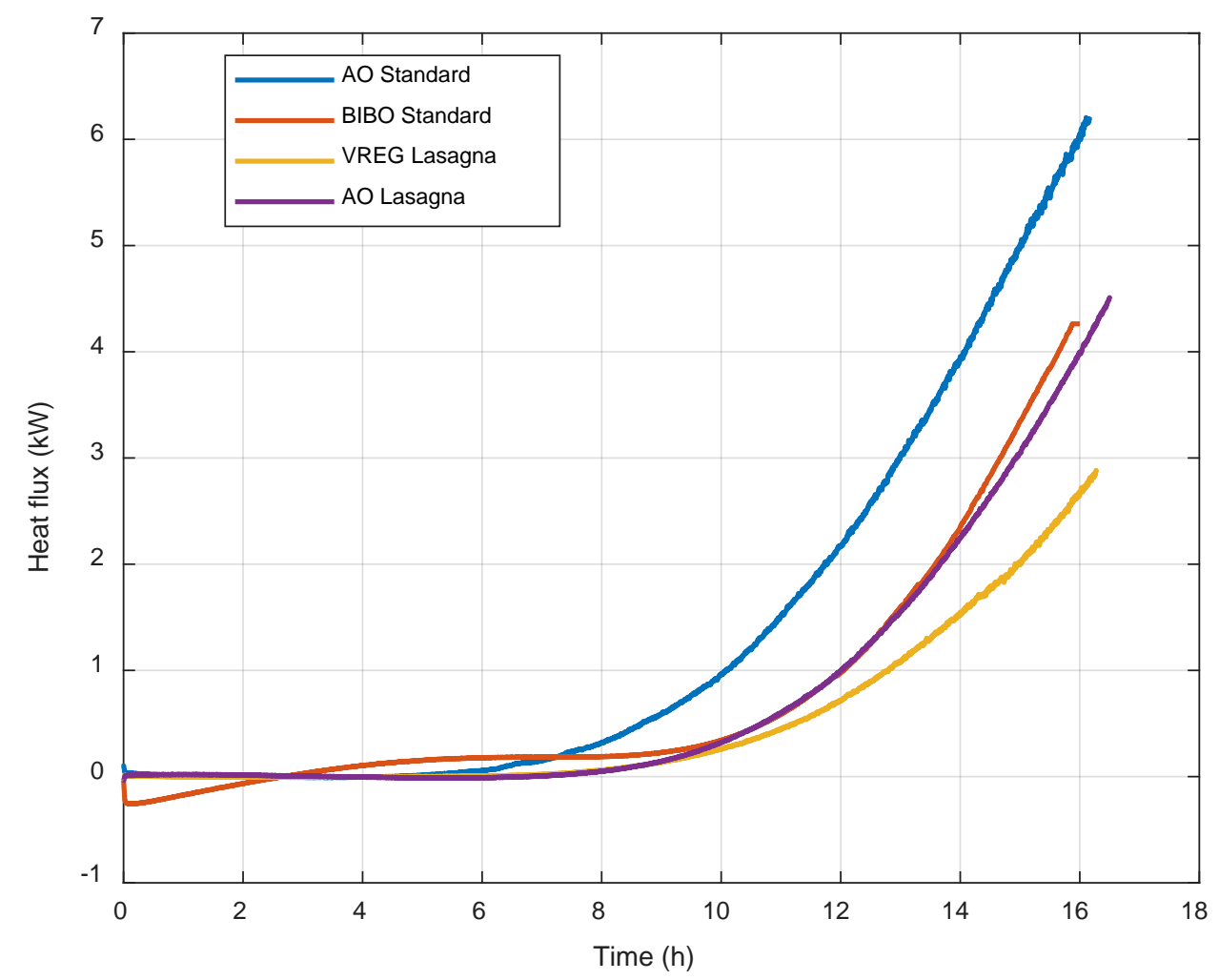

Figure 7. The energy exiting the regenerator (outlet losses) during a charge cycle at $27 \mathrm{~kW}$ as a function of time for each tested configuration.

Results for the $17 \mathrm{~kW}$ charge experiments are summarized in Table 5. Slight differences in terms of charging air flow rate lead to non-perfectly comparable outlet losses results in this case. For this reason they are not reported in the table. Though, for sake of completeness and in order to show a comparison to $27 \mathrm{~kW}$ tests, charging efficiency values are reported.

Table 5. Performance summary for charge cycles at $17 \mathrm{~kW}$ for the four configurations tested.
Test
$\eta_{C H}(\%)$
$\eta_{I I, C H}(\%)$

Standard AO

54.77

21.22

Standard BIBO

56.42

21.86 
Lasagna AO

Lasagna VREG
60.58

60.72
23.92

23.95

As shown in Table 5, the lasagna design gives higher charge efficiencies for the slow charge rate as well. This can be explained by a more even heat distribution, shown in the 3D temperature reconstruction of the rock bed in Figure 6, a steeper thermocline and outlet heat losses increasing only at a larger state of charge than the other configurations. All these features result from the addition of the horizontal insulation layers which prevent buoyancy phenomena. It was observed in the 3D temperature reconstructions that the influence of buoyancy forces can generate cold pockets at the bottom of the rock bed and high temperature air leaving the system prematurely, decreasing the charge efficiency. As was the case for the slow charge tests, the best configuration for the standard design is BIBO, as Figure 6(b) shows a more uniform temperature distribution compared to that of Figure 6(a). However, forcing all hot air flow into through the bottom pipe only can cause local hot spots, large thermal gradients and higher heat storage in the insulation material, which can result in lower charge efficiency and structural damages after a large number of cycles. Analyzing the differences between the $27 \mathrm{~kW}$ and $17 \mathrm{~kW}$ tests, it can also be noted that the higher charging rate improves charge efficiencies, as the larger flow rates increase the heat transfer between hot air and rocks and reduce air flows orthogonal to the flow direction driven by buoyancy forces.

\subsubsection{Pressure drops}

Because of the chosen pipe and valve diameter of $200 \mathrm{~mm}$, main pressure drops were observed in the heater and across the bed. The highest pressure drops were experienced during the charge phase because of the restrictions caused by the heaters and the high volume flow rate due to the high temperatures. It was measured an average of $440 \mathrm{~Pa}$ and $990 \mathrm{~Pa}$ across the heater for the $16 \mathrm{~kW}$ and $27 \mathrm{~kW}$ charge cycles, respectively. The pressure drop across the rock bed was measured $7 \mathrm{~Pa}$ and $11 \mathrm{~Pa}$ for the $16 \mathrm{~kW}$ and 27 $\mathrm{kW}$ charge cycles, respectively. The addition of the insulation layers was found not to alter significantly the pressure drop across the rock bed section. Pressure drops were measured after the airflow temperature at the rock bed inlet reached the set-point temperature. High fluctuations of the pressure readings were observed because of the turbulence of the air flow across the piping systems.

\subsection{Discharge phase results}

The goal of the discharge cycle experiments was to isolate only the discharge phase. Therefore, each experiment started after the same charge cycle, which was chosen as a slow (17 kW) charge for 26 hours with all valves open (AO configuration). The baseline charge cycle ensured that the same amount of energy was input to the rock bed in each case before the discharge cycle started. All the discharge tests lasted 24 hours with an air flow rate of $140 \mathrm{Nm}^{3} / \mathrm{h}$, in order to make the recovered energy and discharge temperature curves more comparable.

The temperature of the recovered air after discharge as a function of the recovered energy is compared for each of the tests in Figure 8. It should be noted that the heater set temperature for the lasagna VREG experiment was $10{ }^{\circ} \mathrm{C}$ lower than for the other experiments, which is the reason for the lower discharge temperature. It can be seen that the lasagna configuration is able to discharge at an elevated temperature for a longer time than the standard configuration due to the better temperature and flow distribution in the rock bed. The discharge temperature of the standard AO configuration drops off first due to the poor temperature distribution and larger temperature gradients in the vertical direction. The general conclusions of the discharge experiments are practically the same as for charging. The lasagna configuration gives a more efficient distribution of flow and better results. Adjusting the valve to guide more flow of cold air through 
the top part of the bed increases discharge temperature and discharge efficiency for both the lasagna and standard configurations.

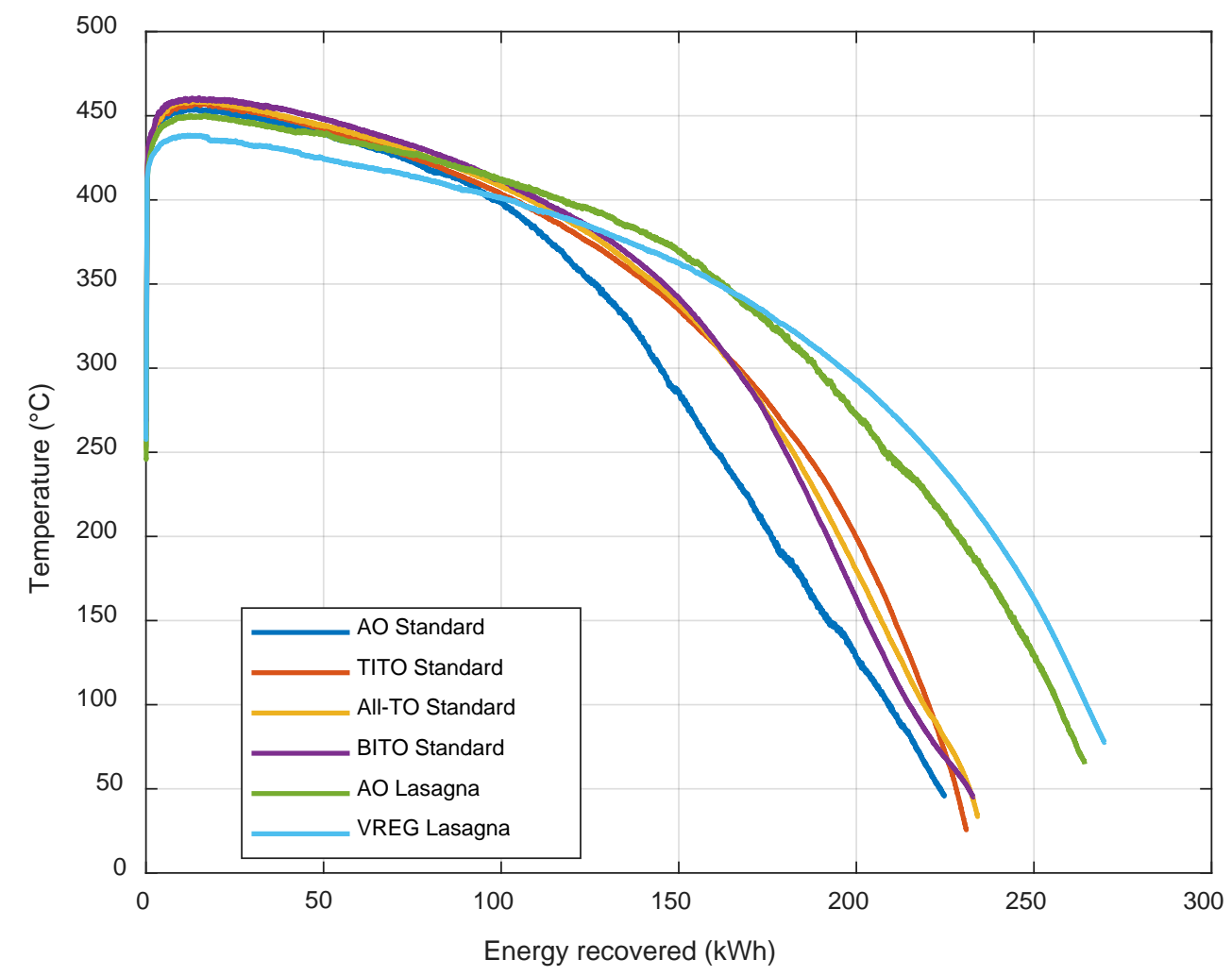

Figure 8. Recovery temperature vs recovered energy for rock beds discharged after a standard charge phase of $17 \mathrm{~kW}$ for $26 \mathrm{~h}$ in the AO configuration.

Apart from a more even heat distribution ensured during the charge, the lasagna design results in a higher state of discharge, which means that more of the heat used to charge the system is recovered. Therefore, the lasagna configuration provides the largest and longest recovery of power, which would result in the most heat provided to a bottoming cycle in a real-life application. TITO is the configuration which results in the best discharge efficiency among the standard tests, due to a recovery air flow which interacts with most of the rock bed due to buoyancy forces.

\subsection{Roundtrip results}

The roundtrip efficiency of the different flow configurations and charge rates were tested. In these experiments, the bed was started from a fully discharged state, charged at a rate of $27 \mathrm{~kW}$ for a specific valve configuration, and then discharged with an air flow rate of $140 \mathrm{Nm}^{3} / \mathrm{h}$ with a valve configuration corresponding to the charge cycle. The discharge cycle is started within a few minutes of the end of the charge cycle in each case. The results are summarized in Table 6.

In the roundtrip experiments, it is important to consider that the small scale test setup has a large amount of thermal capacity associated with the pipes, valves, housing, insulation and other components upstream of the rock bed. Although the heat storage in these components is not considered in the measured energy 
stored in the rocks in Eq. (8-11), these components are all still warm from the charge process when the discharge process starts. Therefore, much of the recovered energy in the roundtrip experiments is from the external equipment, but there was not sufficient temperature measurements on that equipment to quantify the energy stored in them. In a real world application, this energy would be lower compared to that stored in the rock bed. Heat stored in the external equipment may not be recoverable in a real system if there are days or even weeks between the charge and discharge cycles. Based on these considerations, the roundtrip results are considered less reliable than charge and discharge results. The energy recovered from these roundtrip experiments is also higher than what can be expected from results presented in Section 4.1 due to the energy recovered in the external equipment. Furthermore, the reliability of the results is affected by a slightly lower charge flow rate in the lasagna AO configuration, which is reflected as a lower provided energy. The charge efficiencies are more reliable and give better indications of the performance of each configuration.

Nevertheless, Figure 9 shows the recovered air temperature for the different roundtrip tests as a function of the percentage of energy discharged, and shows that the Lasagna VREG configuration is able to recover the heat at a higher temperature than the standard configuration. Table 6 shows that the lasagna configuration with AO configuration gives the highest roundtrip efficiency while the standard design with AO configuration gives the lowest roundtrip efficiency. 


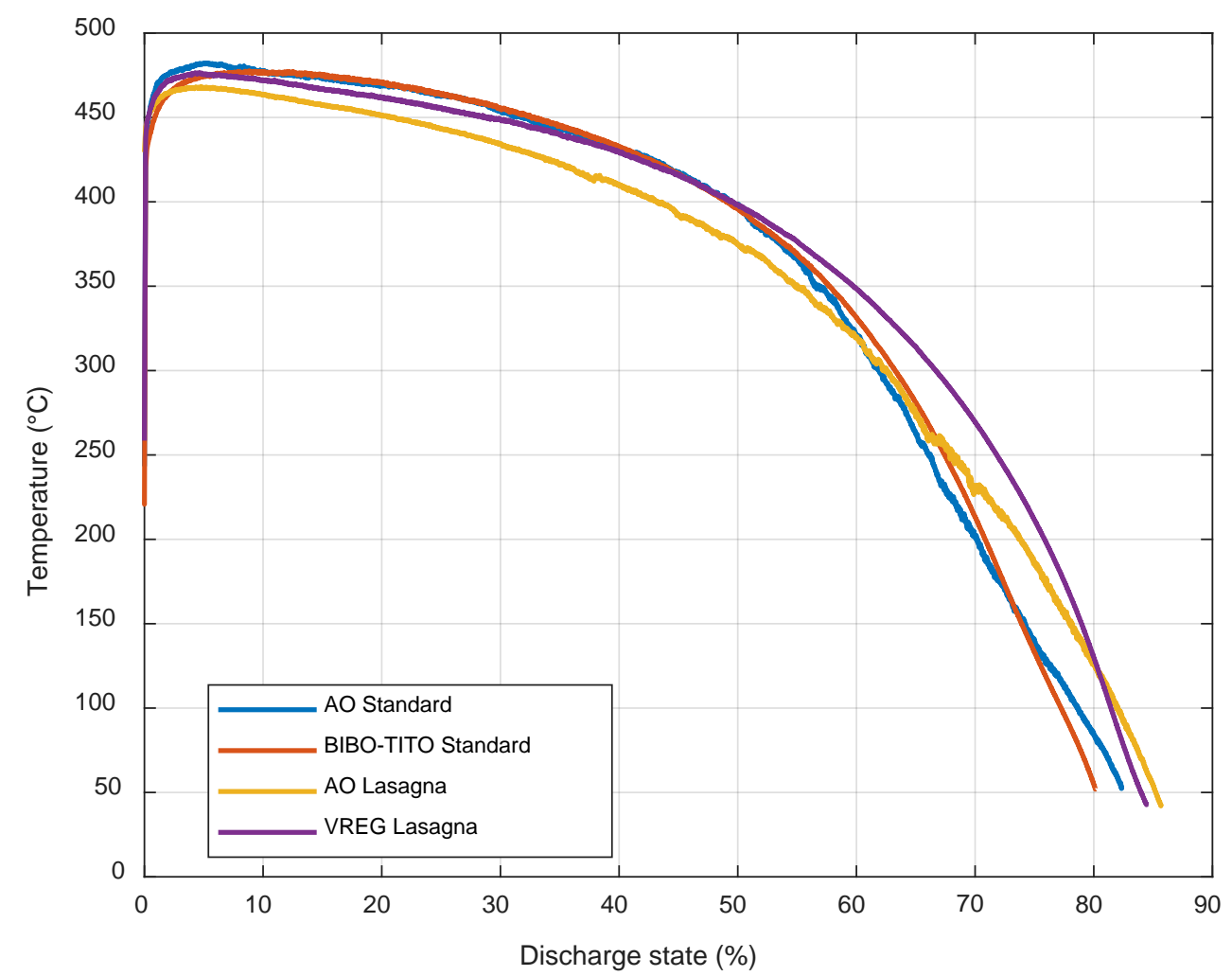

Figure 9. Recovery temperature vs state of the discharge cycle for a $27 \mathrm{~kW}$ charge cycle followed by a discharge at $140 \mathrm{Nm}^{3} / \mathrm{h}$. Each experiment started from a fully discharged bed.

Table 6. Summary of performance parameters from roundtrip tests for a $27 \mathrm{~kW}$ charge cycle followed by a discharge at $140 \mathrm{Nm} / \mathrm{h}$.
Test
$\eta_{R T}(\%)$
$\eta_{I I, R T}(\%)$
Final discharge state
(\%)

\begin{tabular}{cccc}
\hline Standard AO & $62.93 \%$ & 21.16 & 82 \\
Standard BIBO-TITO & $67.27 \%$ & 23.42 & 80 \\
Lasagna AO & $68.43 \%$ & 23.62 & 86 \\
Lasagna VREG & $66.95 \%$ & 23.13 & 85
\end{tabular}

The temperatures measured by thermocouples in all four rows shown in Figure 4 in the bed as a function of time are shown for the standard AO and lasagna AO configurations during the discharge phase are shown in Figure 10. The profiles show that the lasagna is more effective at extracting the energy from the rocks, especially at the top of the rock bed. The temperature of the standard AO is significantly higher than the lasagna AO for the top two rows of thermocouples at the end of the discharge cycle. Figure 10(a) shows that the top section of the lasagna configuration is more discharged than for the standard design. The higher residual temperatures exhibited by the standard design indicate that the bed is not as efficiently discharged. 
(A)

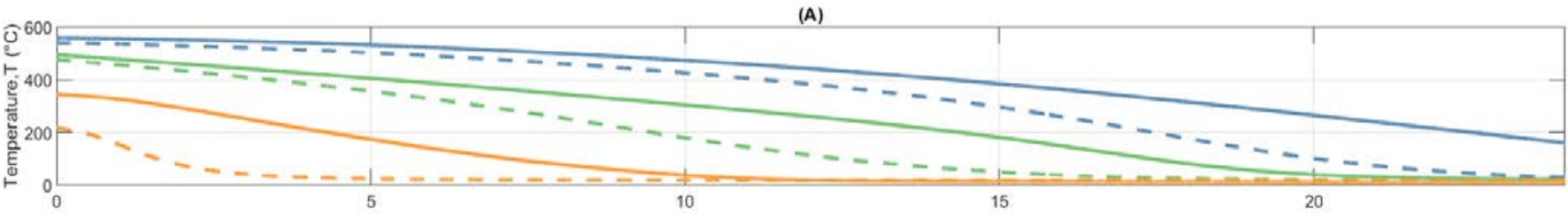

(B)

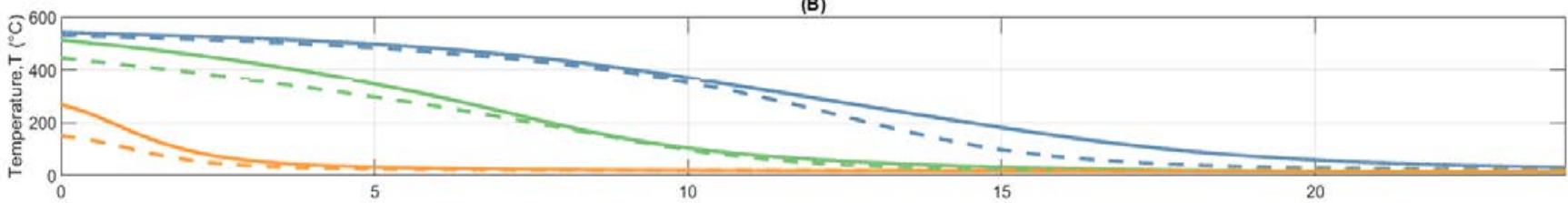

(C)

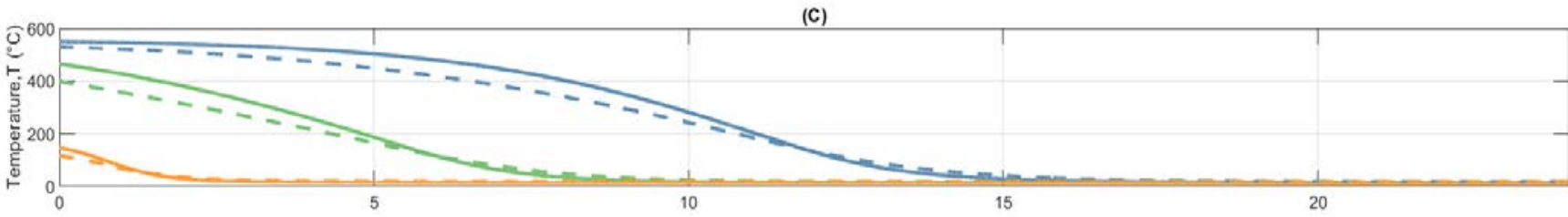

(D)

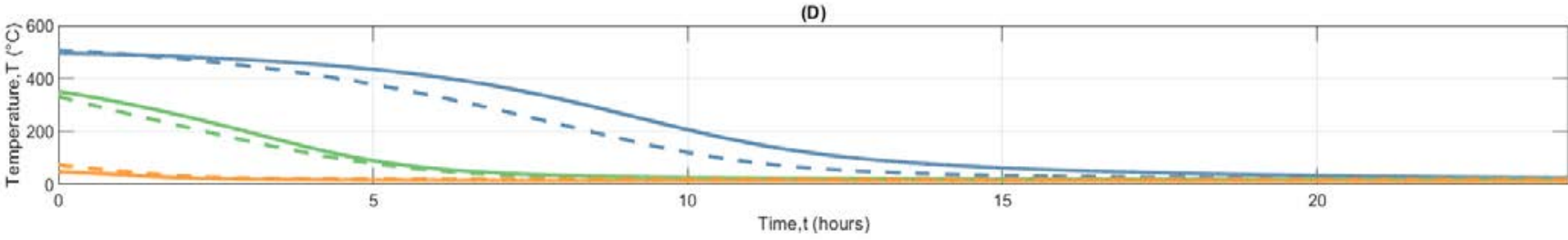

Figure 10. Temperature evolution in time for thermocouple columns 1,3,4 in each row of thermocouples shown in Figure 4 for the discharge phase of the roundtrip experiments. A: top layer (Row 1); B: middle-upper (Row 2); C: middle-lower (Row 3); D: bottom (Row 4). Solid lines: AO Standard discharge; dashed lines: AO Lasagna discharge. Blue line: hot end; green: center; orange: cold end.

Results show that the lasagna configuration and the cycle BIBO-TITO have a higher roundtrip efficiency compared to the standard AO configuration, in accordance with the results previously shown. It is important to notice the final state of discharge of the rock bed in the four configurations, which is an index of the air flow distribution during the discharge phase and its capability of recovering heat. Although the BIBO-TITO and lasagna cycles have similar values of roundtrip efficiencies, a great part of the heat recovered in the BIBO-TITO comes from the insulation layers and external equipment, whereas the energy for the lasagna design comes primarily from the rock bed. Figure 10 shows that a "hot pocket" is still present in the upper hot-end region of the AO standard design after 24 hours of discharge, which is not found in the AO Lasagna test. Similar results were found for the other two tests. In real-life applications, this aspect is can be important, as it can result in structural damages.

Finally, the heat capacity of the main components that are in contact with both the hot air during charge and recovered air during discharge was studied. It is estimated that $22.3 \%$ of the thermal storage capacity is located outside the rock bed in this small-scale setup, see Table 7. This heat capacity is the source of significant uncertainty, especially in round trip experiments. However the relative magnitude of the thermal capacity in the external equipment is expected to be much lower for an industrial scale system. 
Table 7. Heat capacity of the main components that are in contact with both hot air during charge cycles and recovered air during discharge cycles.

\begin{tabular}{ccc}
\hline Material & Heat capacity (kJ/K) & $\begin{array}{c}\text { Heat capacity overall } \\
\text { fraction (\%) }\end{array}$ \\
\hline Rocks & 2970 & 73.7 \\
\hline Soft insulation & 360 & 8.94 \\
\hline Hard insulation & 350 & 8.69 \\
\hline $\begin{array}{c}\text { Steel housing } \\
\text { Insulated pipes } \\
\text { common to charge and } \\
\text { discharge }\end{array}$ & 172 & 4.27 \\
\hline
\end{tabular}

It is also important to mention that the round trip operations have not been optimized. Heat losses in the inlet pipes and at the outlet strongly affect the thermal efficiency of the storage. This proves that a particular focus should be put on the thermal integration of the storage facility, considering short pipe lengths between the heater and the hot end, effective thermal insulation and recirculation of the outlet air at the cold end. Recirculation of outlet air likely would require a high temperature fan and may require specially design heaters. Assuming an optimized system in which the inlet and outlet losses are minimized, a first law roundtrip efficiency up to $\sim 83 \%$ could be obtained for this plant with a layered configuration and valve regulation.

\subsection{Post-operation inspection}

These initial tests for the standard configuration were run for a total of 22 heating and cooling cycles over a time span of around 1100 hours. After the experiments were finished, samples were collected from different horizontal and vertical levels from the rock bed to see the effect of prolonged and different heat exposure to the rocks. The rock consists mainly of plagioclase and pyroxene. Generally, the rocks were intact, but turned slightly brownish on their surface when they were exposed to temperatures over $150^{\circ} \mathrm{C}$. Microscopically the rocks showed some reddening in small fractures and along the cleavage in the pyroxene that were exposed to higher temperatures, as shown in Figure 11, but the overall strength of the rock was not diminished. A large, single pyroxene crystal is shown in the inset of Figure 11(a). The rocks at the hottest part of the bed (top section of the hot end) are shown in Figure 11(b), and the inset shows oxidation of some iron in the pyroxene along cleavage. 

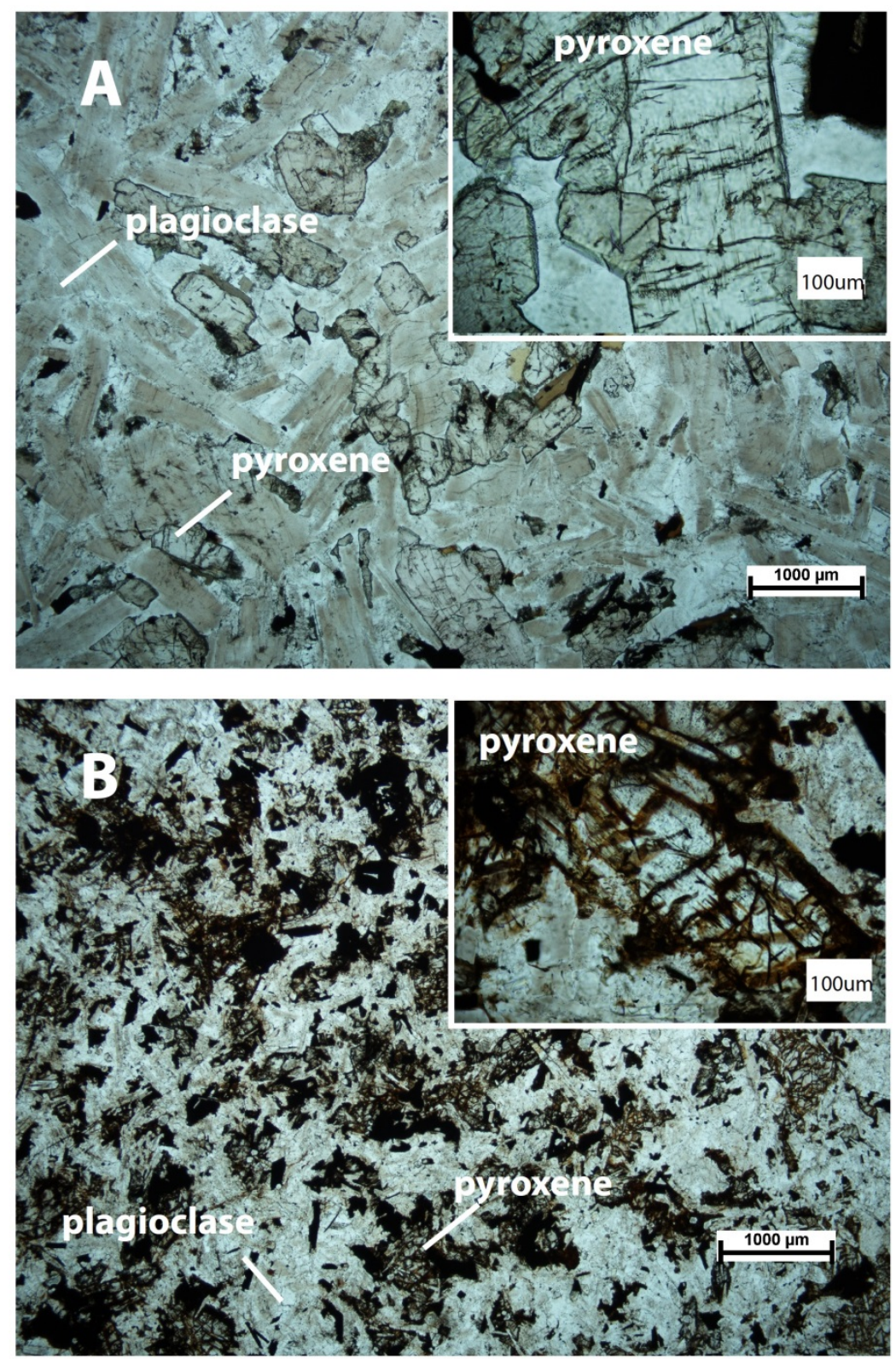

Figure 11. Microphotographs of thin sections of the diabase rocks used in the experiment. A) before the experiment, unaltered diabase. B) Diabase from the top section of the hot end after the experiment.

\section{Conclusions}

This work presented the construction and experimental testing of a rock bed prototype for high temperature thermal energy storage. A $450 \mathrm{kWh}_{\text {th }}$ storage unit was built and tested with a horizontal air flow orientation, which was chosen to ensure flexibility and cost-effective scalability of the design. A systematic study was performed to determine which rock types can be suitable for the temperature ranges expected for this technology and it was found that granite, dunite, and quartzite are not suitable due to either instable constituents or high oxidation. Other rock types such as diabase, basalt and magnetite are good candidates for HTTES applications.

Performing different charge and discharge cycles, it was found that buoyancy forces significantly affected the temperature distribution across the bed and consequently the amount of energy that can be stored and 
recovered. The hot air entering the cold bed tended to migrate to the upper section of the rock bed, resulting in uneven heating and outlet losses. The same effect was observed during the discharge phase with the fresh air preferably occupying the bottom of the rock bed and leaving hot pockets in the top sections of the bed, thus reducing efficiency. These phenomena were analyzed and characterized for different testing conditions using a 3D temperature reconstruction tool and by calculating figures of merit such as charge and round trip efficiencies. It was found that a faster air flow across the bed, corresponding to a higher charging rate, showed reduced losses from buoyancy forces due to the flow inertia. With a charging rate of $27 \mathrm{~kW}$, compared to $17 \mathrm{~kW}$, a more uniform heat distribution and a more vertical thermal gradient were propagated from the hot to the cold end. A gain of 7\% in efficiency during charging was observed for the Standard AO configuration. Integrating thin thermally insulating layers in the rock bed that could prevent the air from flowing vertically significantly limited the impact of the buoyancy forces. Lasagna AO proved to have a 6\% higher charging efficiency compared to Standard BIBO. Finally, fine regulation of the valves at the hot and cold ends proved to effectively provide a more uniform air flow through the rock bed. This effect was more significantly observed for the case at faster air flow rates with an additional gain of $4 \%$ for the Lasagna VREG configuration compared to the Lasagna AO. Comparing the efficiency during the charge phase for Standard AO (17 kW) and Lasagna VREG $(27 \mathrm{~kW})$ a total increase of $17 \%$ was obtained by implementing these solutions.

The difference in performance between the configurations could not clearly be observed in the evaluation of the round trip efficiency because of the thermal mass of the insulation and of the pipes, which represented more than a fourth of the rock bed heat capacity. The extra heat stored in these components, not accounted in the charging efficiency, would still be recovered during a discharge cycle and gave similar roundtrip efficiencies for Standard BIBO-TITO, Lasagna AO, and Lasagna VREG of around 67-68\%. This would not happen in an industrial scale rock bed storage unit where the pipe and insulation thermal mass would represent a much lower percentage of the overall heat capacity. Nevertheless, the advantage of having a layered configuration and a valve adjustment could still be observed by comparing the discharge temperature curves. Lasagna AO and Lasagna VREG showed the highest discharge temperatures compared to the other configurations. It was also observed that the heat losses from the pipes between the heater and the hot end represent a significant limitation to the storage thermal efficiency, as well as the losses due to the hot air prematurely leaving the rock bed at the cold end. Pipes between the heater and hot end should therefore be minimized in length and well insulated, and a layered configuration with adjusted air flow should be adopted when using a horizontal flow configuration. An increased round trip efficiency of $83 \%$ was estimated for this optimized case.

Experiments presented in this study show the performance challenges of using a horizontal flow in a rock bed HTTES. In applications where thermal efficiency is critical, it will probably be advantageous to use a vertical flow configuration. The concept of using insulation layers to correct flow channeling may be applicable to vertical flow rock beds as well to correct for flow or temperature maldistributions.

Finally, it is important to remember that thermal efficiencies were defined in this work purely as figures of merit to compare performance of different design solutions. However, the thermal efficiency of rock bed plant in industrial high temperature thermal energy storage applications could reach much higher values around $90-95 \%$ depending on the charge/discharge cycles history and duration.

\section{Acknowledgements}

The authors would like to express their gratitude to the Danish Energy Technology Development and Demonstration Program (EUDP) for funding this work (Contract No. EUDP 64016-0027). The authors 
would also like to thank Allan Schrøder Pedersen, Mike Wichmann, and Jens Borchsenius for their valuable input and support.

\section{References}

[1] Kroposki B, Johnson B, Zhang Y, Gevorgian V, Denholm P, Hodge BM, et al. Achieving a 100\% Renewable Grid: Operating Electric Power Systems with Extremely High Levels of Variable Renewable Energy. IEEE Power Energy Mag 2017;15:61-73. doi:10.1109/MPE.2016.2637122.

[2] Ellabban O, Abu-Rub H, Blaabjerg F. Renewable energy resources: Current status, future prospects and their enabling technology. Renew Sustain Energy Rev 2014;39:748-64. doi:10.1016/j.rser.2014.07.113.

[3] Komor P, Anderson H, Kempener R. "SMART GRIDS,” IRENA - International Renewable Energy Agency 2013.

[4] Smart Energy Networks, The Partnership Smart Energy Networks. Vision for smart energy in Denmark - Research, Development and Demonstration. Technical University of Denmark, 2015.

[5] Ekman CK, Jensen SH. Prospects for large scale electricity storage in Denmark. Energy Convers Manag 2010;51:1140-7. doi:10.1016/j.enconman.2009.12.023.

[6] SANDIA NL. Energy Storage for the Electricity Grid: Benefits and Market Potential Assessment Guide. Sand2010-0815 2010;20:232. doi:SAND2010-0815.

[7] Zakeri B, Syri S. Corrigendum to "Electrical energy storage systems: A comparative life cycle cost analysis" [Renew. Sustain. Energy Rev. 42 (2015) 569-596]. Renew Sustain Energy Rev 2015;53:1634-5. doi:10.1016/j.rser.2015.09.095.

[8] Luo X, Wang J, Dooner M, Clarke J. Overview of current development in electrical energy storage technologies and the application potential in power system operation. Appl Energy 2015;137:511-36. doi:10.1016/j.apenergy.2014.09.081.

[9] Chen H, Cong TN, Yang W, Tan C, Li Y, Ding Y. Progress in electrical energy storage system: A critical review. Prog Nat Sci 2009;19:291-312. doi:10.1016/j.pnsc.2008.07.014.

[10] Weber AZ, Mench MM, Meyers JP, Ross PN, Gostick JT, Liu Q. Redox flow batteries: A review. J Appl Electrochem 2011;41:1137-64. doi:10.1007/s10800-011-0348-2.

[11] Amiryar ME, Pullen KR. A review of flywheel energy storage system technologies and their applications. Appl Sci 2017;7. doi:10.3390/app7030286.

[12] Madlener R, Latz J. Economics of centralized and decentralized compressed air energy storage for enhanced grid integration of wind power. Appl Energy 2013;101:299-309. doi:10.1016/j.apenergy.2011.09.033.

[13] IEC. Executive summary. Bus Strateg Environ 2007;2:1-3. doi:10.1002/bse.3280020501.

[14] MacKay D, Winse N. The future role for energy storage in the UK Main Report. 2011.

[15] Luo Y, Wu X yu, Shi Y, Ghoniem AF, Cai N. Exergy analysis of an integrated solid oxide electrolysis cell-methanation reactor for renewable energy storage. Appl Energy 2018;215:371-83. doi:10.1016/j.apenergy.2018.02.022.

[16] Laughlin RB. Pumped thermal grid storage with heat exchange. J Renew Sustain Energy 2017;9:023. doi:10.1063/1.4994054.

[17] Desrues T, Ruer J, Marty P, Fourmigué JF. A thermal energy storage process for large scale electric applications. Appl Therm Eng 2010;30:425-32. doi:10.1016/j.applthermaleng.2009.10.002. 
[18] Arabkoohsar A, Andresen GB. Dynamic energy, exergy and market modeling of a High Temperature Heat and Power Storage System. Energy 2017;126:430-43. doi:10.1016/j.energy.2017.03.065.

[19] Kerskes H, Bertsch F, Mette B, Wörner A, Schaube F. Thermochemische Energiespeicher. ChemieIngenieur-Technik 2011;83:2014-26. doi:10.1002/cite.201100091.

[20] Demirbas MF. Thermal Energy Storage and Phase Change Materials: An Overview. Energy Sources, Part B Econ Planning, Policy 2007;1:85-95. doi:10.1080/009083190881481.

[21] Hasnain SM. Review on sustainable thermal energy storage technologies, part I: Heat storage materials and techniques. Energy Convers Manag 1998;39:1127-38. doi:10.1016/S01968904(98)00025-9.

[22] Barbour E, Mignard D, Ding Y, Li Y. Adiabatic Compressed Air Energy Storage with packed bed thermal energy storage. Appl Energy 2015;155:804-15. doi:10.1016/j.apenergy.2015.06.019.

[23] Kuravi S, Trahan J, Goswami DY, Rahman MM, Stefanakos EK. Thermal energy storage technologies and systems for concentrating solar power plants. Prog Energy Combust Sci 2013;39:285-319. doi:10.1016/j.pecs.2013.02.001.

[24] Duffie JA, Beckman WA, McGowan J. Solar Engineering of Thermal Processes. vol. 53. John Wiley \& Sons; 1985. doi:10.1119/1.14178.

[25] Rosen JB. Kinetics of a fixed bed system for solid diffusion into spherical particles. J Chem Phys 1952;20:387-94. doi:10.1063/1.1700431.

[26] Pedersen AS, Engelbrecht K, Soprani S, Wichmann M, Borchsenius J, Marongiu F, et al. HighTemperature Thermal Energy Storage for electrification and district heating, 2018.

[27] Shitzer A, Levy M. Transient Behavior of a Rock-Bed Thermal Storage System Subjected to Variable Inlet Air Temperatures: Analysis and Experimentation. J Sol Energy Eng 1983;105:200. doi:10.1115/1.3266366.

[28] Flueckiger S, Yang Z, Garimella S V. An integrated thermal and mechanical investigation of moltensalt thermocline energy storage. Appl Energy 2011;88:2098-105. doi:10.1016/j.apenergy.2010.12.031.

[29] Schumann TEW. Heat transfer: A liquid flowing through a porous prism. J Franklin Inst 1929;208:405-16. doi:10.1016/S0016-0032(29)91186-8.

[30] Ismail KAR, Stuginsky R. Parametric study on possible fixed bed models for pcm and sensible heat storage. Appl Therm Eng 1999;19:757-88. doi:10.1016/S1359-4311(98)00081-7.

[31] Beasley DE, Clark JA. Transient response of a packed bed for thermal energy storage. Int J Heat Mass Transf 1984;27:1659-69. doi:10.1016/0017-9310(84)90278-3.

[32] Waked AM. Solar energy storage in rocks. Sol Wind Technol 1986;3:27-31. doi:10.1016/0741983X(86)90045-7.

[33] Mawire A, McPherson M. Experimental and simulated temperature distribution of an oil-pebble bed thermal energy storage system with a variable heat source. Appl Therm Eng 2009;29:1086-95. doi:10.1016/j.applthermaleng.2008.05.028.

[34] Hänchen M, Brückner S, Steinfeld A. High-temperature thermal storage using a packed bed of rocks Heat transfer analysis and experimental validation. Appl Therm Eng 2011;31:1798-806. doi:10.1016/j.applthermaleng.2010.10.034.

[35] Jalalzadeh-Azar AA, Steele WG, Adebiyi GA. Heat Transfer in a High-Temperature Packed Bed Thermal Energy Storage System-Roles of Radiation and Intraparticle Conduction. J Energy Resour 
Technol 2008;118:50. doi:10.1115/1.2792693.

[36] Nsofor EC, Adebiyi GA. Measurements of the gas-particle convective heat transfer coefficient in a packed bed for high-temperature energy storage. Exp Therm Fluid Sci 2001;24:1-9. doi:10.1016/S0894-1777(00)00047-9.

[37] Zanganeh G, Pedretti A, Zavattoni S, Barbato M, Steinfeld A. Packed-bed thermal storage for concentrated solar power - Pilot-scale demonstration and industrial-scale design. Sol Energy 2012;86:3084-98. doi:10.1016/j.solener.2012.07.019.

[38] Geissbühler L, Kolman M, Zanganeh G, Haselbacher A, Steinfeld A. Analysis of industrial-scale high-temperature combined sensible/latent thermal energy storage. Appl Therm Eng 2016;101:65768. doi:10.1016/j.applthermaleng.2015.12.031.

[39] Agalit H, Zari N, Maalmi M, Maaroufi M. Numerical investigations of high temperature packed bed TES systems used in hybrid solar tower power plants. Sol Energy 2015;122:603-16. doi:10.1016/j.solener.2015.09.032.

[40] Coutier JP, Farber EA. Two applications of a numerical approach of heat transfer process within rock beds. Sol Energy 1982;29:451-62. doi:10.1016/0038-092X(82)90053-6.

[41] Allen KG, von Backström TW, Kröger DG. Packed bed pressure drop dependence on particle shape, size distribution, packing arrangement and roughness. Powder Technol 2013;246:590-600. doi:10.1016/j.powtec.2013.06.022.

[42] Zavattoni S a, Barbato MC, Pedretti A, Zanganeh G, Steinfeld A. Cfd Simulations of a Pebble Bed Thermal Energy Storage System Accounting for Porosity Variations Effects. SolarPACES, vol. 24636, 2011, p. 3-4.

[43] Ergun S. Fluid flow through packed columns. Chem Eng Prog 1952;48:89-94.

[44] Allen KG, von Backström TW, Kröger DG. Rock bed pressure drop and heat transfer: Simple design correlations. Sol Energy 2015;115:525-36. doi:10.1016/j.solener.2015.02.029.

[45] Allen KG, Von Backström TW, Kröger DG. Packed rock bed thermal storage in power plants: Design considerations. Energy Procedia 2013;49:666-75. doi:10.1016/j.egypro.2014.03.072.

[46] Grosu Y, Faik A, Ortega-Fernández I, D’Aguanno B. Natural Magnetite for thermal energy storage: Excellent thermophysical properties, reversible latent heat transition and controlled thermal conductivity. Sol Energy Mater Sol Cells 2017;161:170-6. doi:10.1016/j.solmat.2016.12.006.

[47] Tiskatine R, Oaddi R, El Cadi R, Bazgaou A, Bouirden L, Aharoune A, et al. Suitability and characteristics of rocks for sensible heat storage in CSP plants. Sol Energy Mater Sol Cells 2017;169:245-57. doi:10.1016/j.solmat.2017.05.033.

[48] Somerton CW, Wood P. Effect of Walls in Modeling Flow through Porous Media. J Hydraul Eng 2008;114:1431-48. doi:10.1061/(asce)0733-9429(1988)114:12(1431).

[49] ASHRAE. ASHRAE Handbook of Fundamentals. vol. 30329. 2009. doi:10.1039/c1cs15219j.

[50] Ofuchi K, Kunii D. Heat-Transfer Characteristics of Packed Beds With Stagnant Fluids. Int J Heat Mass Transf 1965;8:749-57.

[51] Beek J. Design of Packed Catalytic Reactors. Adv Chem Eng 1962;3:203-71. doi:10.1016/S00652377(08)60060-5.

[52] Engelbrecht K, Bahl CRH. Evaluating the effect of magnetocaloric properties on magnetic refrigeration performance. J Appl Phys 2010;108:123918. doi:10.1063/1.3525647. 
[53] Soprani S, Marongiu F, Engelbrecht K. Data Set for Design and Testing of a Horizontal Rock Bed for High Temperature Thermal Energy Storage. Under Rev. doi:10.11583/DTU.7980065. 